\title{
An Experimental and Theoretical Investigation into the Hydrolysis of Dichloro(Ethylenediamine)Platinum(II) Via Electrospray Mass Spectrometry and Density Functional Theory
}

\author{
Akihiko Yoshikawa, Stephan B. H. Bach, and Grant N. Merrill \\ Department of Chemistry, The University of Texas at San Antonio, San Antonio, San Antonia, Texas, USA
}

Dichloro(ethylenediamine)platinum(II), $\mathrm{Pt}(\mathrm{en}) \mathrm{Cl}_{2}$, was dissolved in $\mathrm{H}_{2} \mathrm{O}$ and $\mathrm{D}_{2} \mathrm{O}$, and the resulting aqueous solutions were electrosprayed into a quadrupole ion-trap mass spectrometer. A series of major and minor ionic hydrolysis products were detected. These ions were then subjected to collision-induced dissociation. As an aid in interpreting the experimental results, density functional theory calculations were carried out. These computations permitted the structures and energetics associated with the hydrolysis products to be determined. An understanding of the hydrolysis of $\mathrm{PtenCl}_{2}$ and related coordination complexes is essential in the rational design of metal-based drugs. (J Am Soc Mass Spectrom 2009, 20, 1015-1029) (C) 2009 American Society for Mass Spectrometry

C isplatin, cis-diamminedichloroplatinum(II), (I) occupies an unique place in cancer therapies [1]. drugs. Second, it is structurally simple compared with its organic counterparts. Along with carboplatin, cisdiammine-1,1-cyclobutanedicarboxylatoplatinum(II), (II) these platinum-containing drugs often represent the first-line of attack for many types of cancer [2]. It is, therefore, somewhat surprising that not more platinum coordination complexes have found their way into therapeutic use [3].

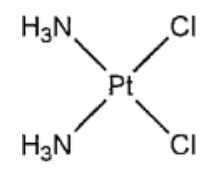

I

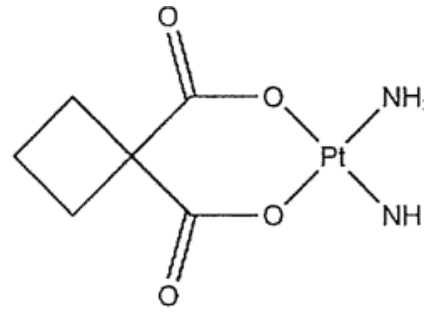

II
Even though cisplatin was approved for use in the United States by the U.S. Food and Drug Administration in 1978, its mechanism of action is still not com-

Address reprint requests to Dr. G. N. Merrill, Department of Chemistry, University of Texas at San Antonio, Antonio, 78249, USA. E-mail: grant.merrill@utsa.edu pletely understood [4]. It is believed that the active species is a hydrolysis product, $\left[\mathrm{Pt}\left(\mathrm{NH}_{3}\right)_{2} \mathrm{Cl}\left(\mathrm{H}_{2} \mathrm{O}\right)\right]^{+}$. This cation coordinates with one of the nitrogencontaining bases of deoxyribonucleic acid (DNA) with the loss of water. The second chlorine anion is lost via hydrolysis, which permits it to interact with a second nitrogen-containing base in DNA. Cell proteins responsible for DNA repair subsequently bind tightly to the cisplatin-DNA adduct. This binding in turn hampers further DNA repair leading to cell death via necrosis or apoptosis.

Clearly, hydrolysis plays a pivotal role in the efficacy of these types of drugs. Hydrolysis is also important in the degradation of these compounds, which often lead to toxic compounds and, thus, undesirable side effects [5]. (It was for this very reason that carboplatin has supplanted cisplatin in many cancer therapies.)

Our goal in carrying out the present research was to develop a more thorough understanding of the hydrolysis and degradation processes of platinum coordination complexes. In terms of hydrolysis, the following question was asked: What products are formed upon dissolving these types of coordination complexes in water? Just as important as establishing the identity of the hydrolysis products, we wanted to learn something of the actual mechanisms leading to these species.

In two earlier articles involving palladium coordination complexes, [6] dichloro- and dibromo(ethylenediamine)palladium(II), (III) experimental results 
suggested that simple hydrolysis (eq 1), whereby water molecules displace halides, may not be the only operative pathways.

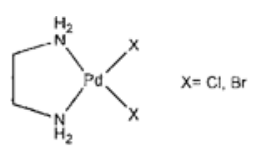

III

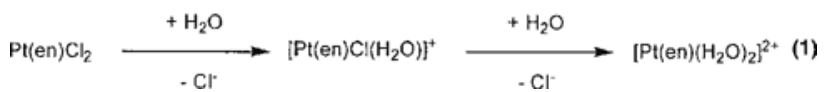

The prevalence of bimetallic complexes (IV) suggest that hydrolysis occur via an aggregation process (eq 2).
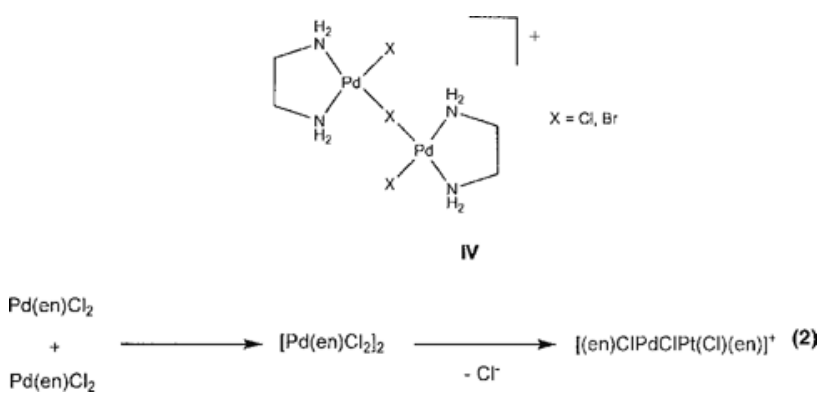

Such bimetallic species have also been observed in other contexts [7].

If new coordination complexes are to be developed in the fight against cancer, their mechanisms of action (including hydrolysis) must first be well understood. Toward this end, we report the results of an experimental and theoretical investigation into the hydrolysis of a related model platinum compound, $\mathrm{Pt}(\mathrm{en}) \mathrm{Cl}_{2}(\mathbf{V})$. The compound in question was dissolved in water, and the resulting aqueous solutions were electrosprayed into a quadrupole ion-trap mass spectrometer (ESMS) [8]. The resulting ions were then subjected to collision-induced dissociation (CID) in an attempt to elucidate their structures [9]. To aid in the interpretation of these experimental results, density functional theory (DFT) calculations were carried out [10]. These calculations established the minimum-energy isomers for the observed ions and permitted their energetics of formation to be determined both in the gas phase and aqueous solution. These results were then compared with those previously obtained for aqueous solutions of $\mathrm{Pd}(\mathrm{en}) \mathrm{Cl}_{2}$.

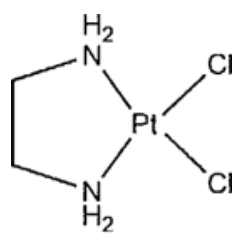

V

\section{Methods}

\section{Experimental}

$\mathrm{Pt}(\mathrm{en}) \mathrm{Cl}_{2}$ (CAS no. 14096-51-6) was purchased from Alfa Aesar (Ward Hill, MA) and used without further purification. The stock solution was prepared by dissolving 1 $\mathrm{mg}$ of $\mathrm{Pt}(\mathrm{en}) \mathrm{Cl}_{2}$ in $1 \mathrm{~mL}$ of deionized water yielding a saturated solution. Deionized water (DI, $18 \mathrm{M} \Omega$ ) was obtained using a Barnstead Nanopure system (Dubuque, IA). The vial was capped and warmed at $37^{\circ} \mathrm{C}$ for 3 days to produce a solution of $\mathrm{pH}$ 5.2. Experiments were also carried out by dissolving $\mathrm{Pt}(\mathrm{en}) \mathrm{Cl}_{2}$ in $\mathrm{D}_{2} \mathrm{O}$.

The aqueous solutions were investigated using a Finnigan LCQ Duo quadrupole ion-trap mass spectrometer (Thermo Finnigan, San Jose, CA) coupled to an electrospray source. All data were collected and analyzed using the Xcalibur software (Thermo Finnigan) in full scan and MS/MS modes. The relative collision energy used for CID was uncalibrated and in arbitrary units. Normalized collision energies (NCE) between 10\% and 30\% were used. The isolation of the parent masses was checked using a NCE of $10 \%$ to verify that only the parent ion was present. The following MS conditions were routinely employed: source voltage $=4.5 \mathrm{kV}$; capillary temperature $=180{ }^{\circ} \mathrm{C}$; capillary voltage $=10.5 \mathrm{~V}$; sheath gas-flow rate $=45$ (arbitrary units); and the auxiliary gas-flow rate $=4$ (arbitrary units). Solutions were introduced by flow injection at a rate of $5 \mu \mathrm{L} / \mathrm{min}$. The windows for CID were between 10 and $20 \mathrm{u}$ to isolate all isomers for individual complexes. Simulations of the stable isotope patterns were made using the Isotope Viewer in Xcalibur. For the simulated mass spectra, the following default settings were used unless otherwise noted: resolution $=1 \mathrm{Da}$ at $5 \%$ height; and charge $=+1$.

\section{Theoretical}

All structures were fully optimized the B3LYP density functional [10]. Structures were deemed converged when the root-mean-square (RMS) and maximum component (MAX) of the gradients fell below 0.004 and $0.012 \mathrm{kcal} /$ mol $\AA$, respectively. To verify that all optimized structures corresponded to minima, Hessians were computed at the same level of theory. Numerical double-differencing of analytical gradients was employed in the calculation of the Hessians. The resulting force constant matrices permitted zero-point energy (ZPE), finite-temperature (FT), and entropic corrections to be computed. The ZPEs and vibrational frequencies were left unscaled. All core electrons were treated with the Stevens, Basch, Krauss, Jasien, and Cundari (SBKJC) effective core potentials (ECP) [11]. The valence electrons were modeled with the SBKJC double-split valence basis set to which a single set of d-type polarization functions [12] were added to all atoms except $\mathrm{H}$ and $\mathrm{Pt}$ atoms.

Solvation effects were calculated with the integral equation formalism of the polarizable continuum model (IEF-PCM) [13] by computing B3LYP single-point ener- 


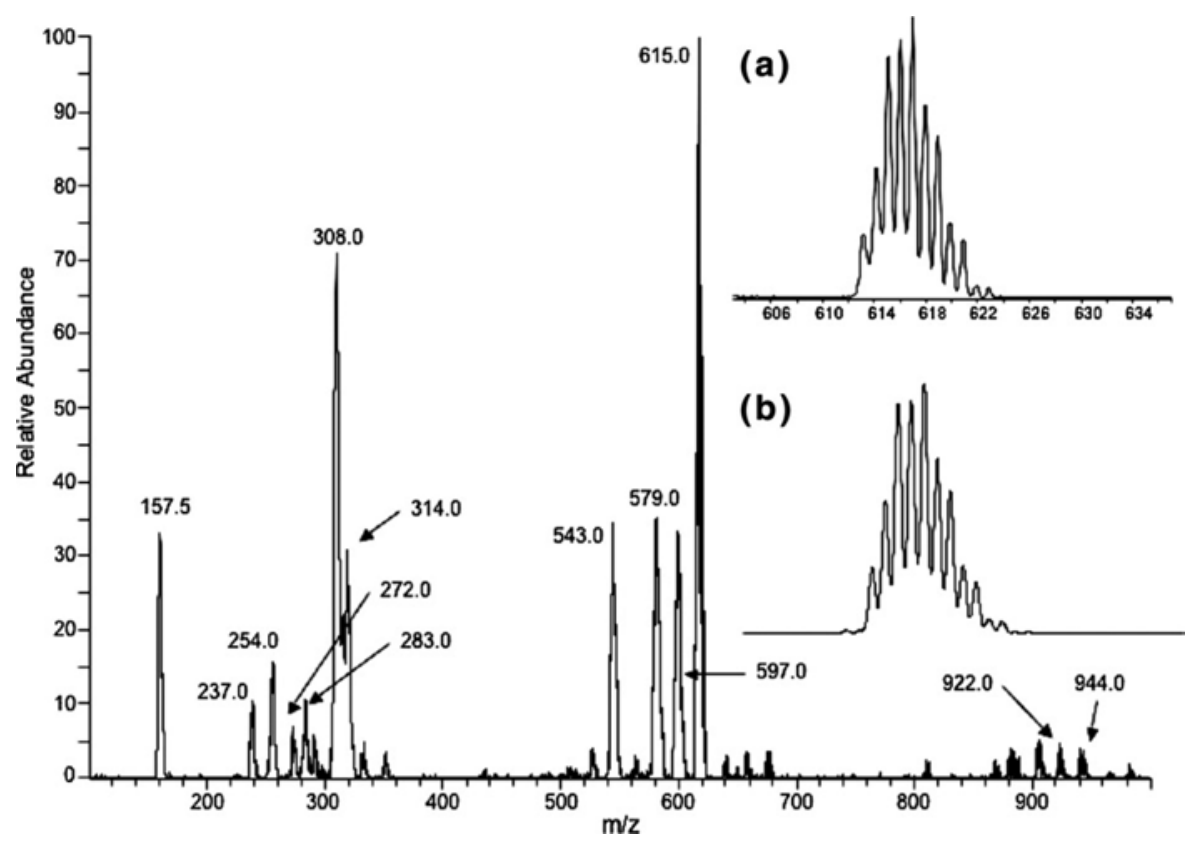

Figure 1. ESMS obtained from a dilute $\mathrm{H}_{2} \mathrm{O}$ solution of $\mathrm{Pt}(\mathrm{en}) \mathrm{Cl}_{2}$. (a) Blow up of base peak region $(m / z=615.0)$. (b) Simulation of base peak region for $\mathrm{C}_{4} \mathrm{H}_{16} \mathrm{Cl}_{3} \mathrm{~N}_{4} \mathrm{Pt}_{2}$.

gies. Cavitation energies were computed via the method of Pierotti and Claverie, $[13,14]$ while repulsion and dispersion energies were determined by the procedure of Amovilli and Mennucci [15]. Solute electron charge density that escaped from the solvent cavity was explicitly treated by the method of Mennucci and Tomasi [16]. Water was used as the solvent.

All calculations were carried out with the GAMESS program [17] running on a Beowulf cluster of personal computers.

\section{Results}

The spectrum obtained by electrospraying a dilute aqueous solution of $\mathrm{Pt}(\mathrm{en}) \mathrm{Cl}_{2}$ into our mass spectrometer is given in Figure 1. Cations with relative abundances greater than $5 \%$ are listed in Table 1 . In an attempt to corroborate the proposed structures, an analogous series of experiments were performed on a solution of $\mathrm{Pt}(\mathrm{en}) \mathrm{Cl}_{2}$ dissolved in deuterated water. The resulting spectrum is presented in Figure 2, and those cations observed with relative abundances greater than 5\% are listed in Table 1. Collision-induced dissociation (CID) was also carried out. Fragment ions with relative abundances greater than $10 \%$ are listed in Table 2.

Theoretical structures for the observed cations are illustrated in Figure 3, and their corresponding theoretical Gibbs energies of their formation are given in Table 3. Theoretical structures for the CID products are shown in Figure 4, and the associated energetics of their forma-

Table 1. Cations observed in electrospray mass spectra from dilute aqueous solutions $\left(\mathrm{H}_{2} \mathrm{O}\right.$ and $\left.\mathrm{D}_{2} \mathrm{O}\right)$ of $\mathrm{Pt}(\mathrm{en}) \mathrm{Cl}_{2}$

\begin{tabular}{|c|c|c|c|c|c|}
\hline \multicolumn{3}{|c|}{$\mathrm{H}_{2} \mathrm{O}$} & \multicolumn{3}{|r|}{$\mathrm{D}_{2} \mathrm{O}$} \\
\hline$m / z$ & $\%$ & Ion & $m / z$ & $\%$ & Ion \\
\hline 615.0 & 100 & {$[2 \mathrm{M}-\mathrm{Cl}]^{+}$} & 623.0 & 100 & {$[2 \mathrm{M}-\mathrm{Cl}]^{+}(\mathrm{d} 8)$} \\
\hline 308.0 & 70 & {$\left[\mathrm{M}-\mathrm{Cl}+\mathrm{H}_{2} \mathrm{O}\right]^{+}$} & 314.0 & 55 & {$\left[\mathrm{M}-\mathrm{Cl}+\mathrm{D}_{2} \mathrm{O}\right]^{+}(\mathrm{d} 4)$} \\
\hline 157.5 & 35 & {$[\mathrm{M}-2 \mathrm{Cl}+\mathrm{en}]^{2+}$} & 161.5 & 25 & {$[\mathrm{M}-2 \mathrm{Cl}+\mathrm{en}]^{2+}(\mathrm{d} 8)$} \\
\hline 543.0 & 35 & {$[2 \mathrm{M}-2 \mathrm{HCl}-\mathrm{Cl}]^{+}$} & 549.0 & 25 & {$[2 \mathrm{M}-2 \mathrm{DCl}-\mathrm{Cl}]^{+}(\mathrm{d} 6)$} \\
\hline 579.0 & 35 & {$[2 \mathrm{M}-\mathrm{HCl}-\mathrm{Cl}]^{+}$} & 586.0 & 30 & {$[2 \mathrm{M}-\mathrm{DCl}-\mathrm{Cl}]^{+}(\mathrm{d} 7)$} \\
\hline 597.0 & 35 & {$\left[2 \mathrm{M}-\mathrm{HCl}-\mathrm{Cl}+\mathrm{H}_{2} \mathrm{O}\right]^{+}$} & 606.0 & 15 & {$\left[2 \mathrm{M}-\mathrm{DCl}-\mathrm{Cl}+\mathrm{D}_{2} \mathrm{O}\right]^{+}(\mathrm{d} 9)$} \\
\hline 314.0 & 30 & {$[\mathrm{M}-\mathrm{HCl}-\mathrm{Cl}+\mathrm{en}]^{+}$} & 321.0 & 45 & {$[\mathrm{M}-\mathrm{DCl}-\mathrm{Cl}+\mathrm{en}]^{+}(\mathrm{d} 7)$} \\
\hline 254.0 & 15 & {$[\mathrm{M}-\mathrm{HCl}-\mathrm{Cl}]^{+}$} & 257.0 & 10 & {$[\mathrm{M}-\mathrm{DCl}-\mathrm{Cl}]^{+}(\mathrm{d} 3)$} \\
\hline 237.0 & 10 & {$\left[\mathrm{M}-\mathrm{HCl}-\mathrm{Cl}-\mathrm{NH}_{3}\right]^{+}$} & 239.0 & 5 & {$\left[\mathrm{M}-\mathrm{DCl}-\mathrm{Cl}-\mathrm{ND}_{3}\right]^{+}(\mathrm{d} 2)$} \\
\hline 283.0 & 10 & {$\left[\mathrm{M}-\mathrm{HCl}-\mathrm{Cl}+\mathrm{CH}_{2}=\mathrm{NH}\right]^{+}$} & 286.0 & 5 & {$\left[\mathrm{M}-\mathrm{DCl}-\mathrm{Cl}+\mathrm{CD}_{2}=\mathrm{ND}\right]^{+}(\mathrm{d} 3)$} \\
\hline 272.0 & 5 & {$\left[\mathrm{M}-\mathrm{HCl}-\mathrm{Cl}+\mathrm{H}_{2} \mathrm{O}\right]^{+}$} & 276.0 & 5 & {$\left[\mathrm{M}-\mathrm{DCl}-\mathrm{Cl}+\mathrm{D}_{2} \mathrm{O}\right]^{+}(\mathrm{d} 3)$} \\
\hline 922.0 & 5 & {$\left[3 \mathrm{M}-\mathrm{HCl}-\mathrm{Cl}+\mathrm{H}_{2} \mathrm{O}\right]^{+}$} & 935.0 & 10 & {$\left[3 \mathrm{M}-\mathrm{DCl}-\mathrm{Cl}+\mathrm{D}_{2} \mathrm{O}\right]^{+}(\mathrm{d} 13)$} \\
\hline 944.0 & 5 & {$[3 \mathrm{M}-\mathrm{Cl}]^{+}$} & 952.0 & 10 & {$[3 \mathrm{M}-\mathrm{Cl}]^{+}(\mathrm{d} 12)$} \\
\hline
\end{tabular}

See Figures 1 and 2 for $\mathrm{H}_{2} \mathrm{O}$ and $\mathrm{D}_{2} \mathrm{O}$ spectra, respectively. 


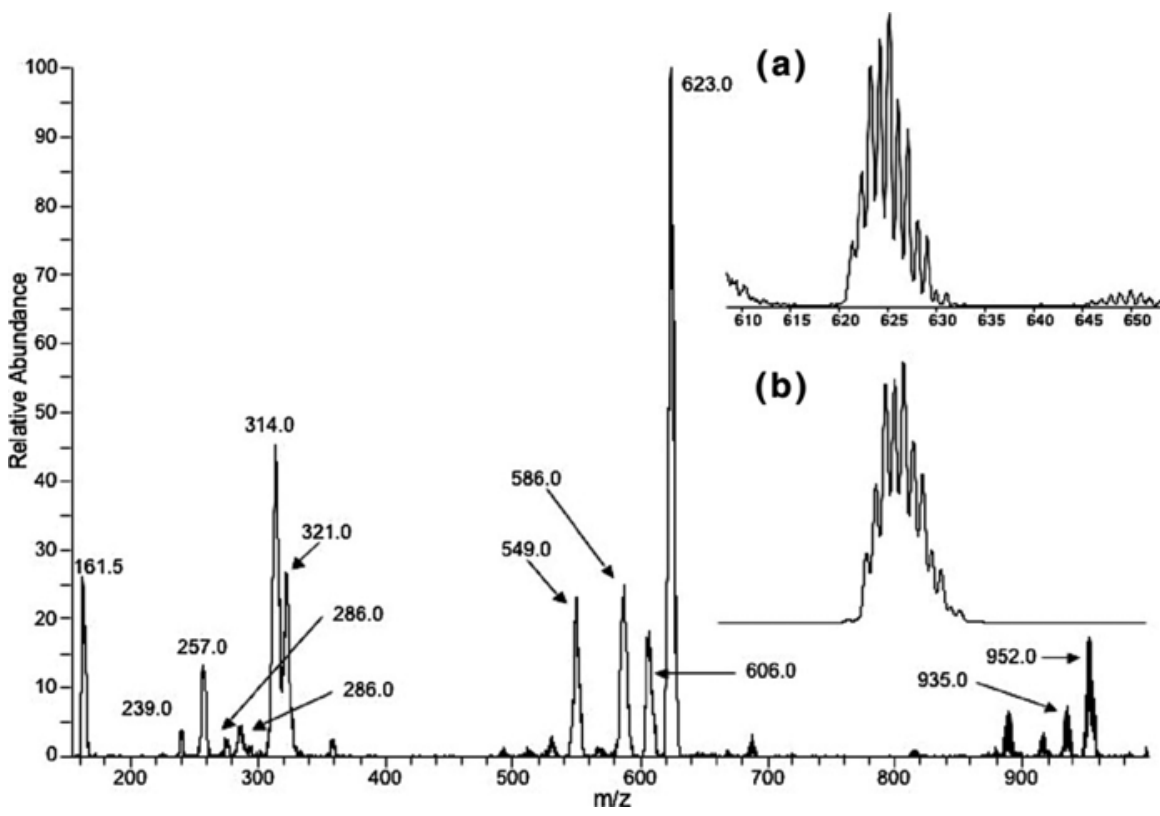

Figure 2. ESMS obtained from a dilute $\mathrm{D}_{2} \mathrm{O}$ solution of $\mathrm{Pt}(\mathrm{en}) \mathrm{Cl}_{2}$. (a) Blow up of base peak region $(m / z=623.0)$. (b) Simulation of base peak region for $\mathrm{C}_{4} \mathrm{H}_{8} \mathrm{D}_{8} \mathrm{Cl}_{3} \mathrm{~N}_{4} \mathrm{Pt}_{2}$.

tion are given in Table 4. A number of unobserved species are postulated for the formation of the observed cations.

\section{Discussion}

\section{The Hydrolysis of Pt(en) $\mathrm{Cl}_{2}$}

The motivation for the present study was to establish the identity of the hydrolysis products formed upon dissolving $\mathrm{Pt}(\mathrm{en}) \mathrm{Cl}_{2}$ in water. The hydrolysis of the parent compound occurs in two steps. In the first step, a water molecule displaces a chloride anion. The experimental Gibbs energy for this reaction has been measured to be $3.6 \pm 5.4 \mathrm{kcal} / \mathrm{mol}$ [18]. Our theoretical aqueous Gibbs energy $\left(\Delta \mathrm{G}_{\mathrm{aq}}=21.9 \mathrm{kcal} / \mathrm{mol}\right)$ is in poor agreement with this experimental value. It must be noted that the theoretical value is for the reaction in eq 3 involving separated reactants and products.

Table 2. Cations observed in collision-induced dissociation (CID) electrospray mass spectra from aqueous solutions $\left(\mathrm{H}_{2} \mathrm{O}\right.$ and $\left.\mathrm{D}_{2} \mathrm{O}\right)$ of $\mathrm{Pt}(\mathrm{en}) \mathrm{Cl}_{2}$

\begin{tabular}{|c|c|c|c|c|c|c|c|}
\hline \multicolumn{4}{|c|}{$\mathrm{H}_{2} \mathrm{O}$} & \multicolumn{4}{|r|}{$\mathrm{D}_{2} \mathrm{O}$} \\
\hline \multirow{2}{*}{$\frac{\text { Parent }}{m / z}$} & \multicolumn{3}{|r|}{ Daughter } & \multirow{2}{*}{$\frac{\text { Parent }}{m / z}$} & \multicolumn{3}{|r|}{ Daughter } \\
\hline & $m / z$ & $\%$ & Ion & & $m / z$ & $\%$ & Ion \\
\hline \multirow[t]{2}{*}{615.0} & 579.0 & 100 & {$[2 \mathrm{M}-\mathrm{HCl}-\mathrm{Cl}]^{+}$} & 623.0 & 586.0 & 100 & {$[2 \mathrm{M}-\mathrm{DCl}-\mathrm{Cl}]^{+}(\mathrm{d} 7)$} \\
\hline & 543.0 & 10 & {$[2 \mathrm{M}-2 \mathrm{HCl}-\mathrm{Cl}]^{+}$} & & 550.0 & 10 & {$[2 \mathrm{M}-2 \mathrm{DCl}-\mathrm{Cl}]^{+}(\mathrm{d} 7)$} \\
\hline \multirow[t]{3}{*}{308.0} & 318.0 & 40 & {$\left[\mathrm{M}-\mathrm{Cl}+\mathrm{N}_{2}\right]^{+}$} & 314.0 & 322.0 & 75 & {$\left[\mathrm{M}-\mathrm{Cl}+\mathrm{N}_{2}\right]^{+}(\mathrm{d} 6)$} \\
\hline & 308.0 & 100 & {$\left[\mathrm{M}-\mathrm{Cl}+\mathrm{H}_{2} \mathrm{O}\right]^{+}$} & & 312.1 & 100 & {$\left[\mathrm{M}-\mathrm{Cl}+\mathrm{D}_{2} \mathrm{O}\right]^{+}(\mathrm{d} 4)$} \\
\hline & 290.0 & 55 & {$\left[\mathrm{M}-\mathrm{Cl}^{+}\right.$} & & 294.0 & 35 & {$[\mathrm{M}-\mathrm{Cl}]^{+}(\mathrm{d} 4)$} \\
\hline \multirow{5}{*}{157.5} & 297.0 & 30 & {$\left[\mathrm{M}-2 \mathrm{Cl}+\text { en }-\mathrm{NH}_{4}\right]^{+}$} & 161.5 & 301.0 & 40 & {$\left[\mathrm{M}-2 \mathrm{Cl}+\text { en }-\mathrm{ND}_{4}\right]^{+}(\mathrm{d} 4)$} \\
\hline & 283.0 & 100 & {$\left[\mathrm{M}-\mathrm{HCl}-\mathrm{Cl}+\mathrm{CH}_{2}=\mathrm{NH}\right]^{+}$} & & 287.0 & 100 & {$\left[\mathrm{M}-\mathrm{DCl}-\mathrm{Cl}+\mathrm{CH}_{2}=\mathrm{ND}\right]^{+}(\mathrm{d} 3)$} \\
\hline & 271.0 & 30 & {$\left[\mathrm{M}-\mathrm{HCl}-\mathrm{Cl}+\mathrm{NH}_{3}\right]^{+}$} & & 277.0 & 25 & {$\left[\mathrm{M}-\mathrm{DCl}-\mathrm{Cl}+\mathrm{ND}_{3}\right]^{+}(\mathrm{d} 3)$} \\
\hline & 61.0 & 30 & $\mathrm{H}_{2} \mathrm{NCH}_{2} \mathrm{CH}_{2} \mathrm{NH}_{3}^{+}$ & & 66.0 & 5 & $\mathrm{D}_{2} \mathrm{NCH}_{2} \mathrm{CH}_{2} \mathrm{ND}_{3}^{+}$ \\
\hline & 59.0 & 55 & $\mathrm{H}_{2} \mathrm{NCH}_{2} \mathrm{CH}=\mathrm{NH}_{2}^{+}$ & & 63.0 & 60 & $\mathrm{D}_{2} \mathrm{NCH}_{2} \mathrm{CH}=\mathrm{ND}_{2}^{+}$ \\
\hline \multirow[t]{3}{*}{543.0} & 526.0 & 100 & {$\left[2 \mathrm{M}-2 \mathrm{HCl}-\mathrm{Cl}-\mathrm{NH}_{3}\right]^{+}$} & 550.0 & 530.0 & 100 & {$\left[2 \mathrm{M}-2 \mathrm{DCI}-\mathrm{Cl}-\mathrm{ND}_{3}\right]^{+}(\mathrm{d} 4)$} \\
\hline & 507.0 & 35 & {$[2 \mathrm{M}-3 \mathrm{HCl}-\mathrm{Cl}]^{+}$} & & 512.0 & 35 & {$[2 \mathrm{M}-3 \mathrm{DCl}-\mathrm{Cl}]^{+}(\mathrm{d} 5)$} \\
\hline & 490.0 & 10 & {$\left[2 \mathrm{M}-3 \mathrm{HCl}-\mathrm{Cl}-\mathrm{NH}_{3}\right]^{+}$} & & 497.0 & 10 & {$\left[2 \mathrm{M}-3 \mathrm{DCl}-\mathrm{Cl}-\mathrm{ND}_{3}\right]^{+}(\mathrm{d} 5)$} \\
\hline 579.0 & 543.0 & 100 & {$[2 \mathrm{M}-2 \mathrm{HCl}-\mathrm{Cl}]^{+}$} & 586.0 & 550.0 & 100 & {$[2 \mathrm{M}-\mathrm{DCl}-\mathrm{HCl}-\mathrm{Cl}]^{+}(\mathrm{d} 7)$} \\
\hline \multirow[t]{3}{*}{597.0} & 579.0 & 100 & {$[2 \mathrm{M}-\mathrm{HCl}-\mathrm{Cl}]^{+}$} & 606.0 & 586.0 & 100 & {$[2 \mathrm{M}-\mathrm{DCl}-\mathrm{Cl}]^{+}(\mathrm{d} 7)$} \\
\hline & 561.0 & 30 & {$\left[2 \mathrm{M}-2 \mathrm{HCl}-\mathrm{Cl}+\mathrm{H}_{2} \mathrm{O}\right]^{+}$} & & 569.0 & 35 & {$\left[2 \mathrm{M}-2 \mathrm{DCl}-\mathrm{Cl}+\mathrm{D}_{2} \mathrm{O}\right]^{+}(\mathrm{d} 6)$} \\
\hline & 543.0 & 30 & {$[2 \mathrm{M}-2 \mathrm{HCl}-\mathrm{Cl}]^{+}$} & & 549.0 & 45 & {$[2 \mathrm{M}-2 \mathrm{DCl}-\mathrm{Cl}]^{+}(\mathrm{d} 6)$} \\
\hline \multirow[t]{2}{*}{254.0} & 254.0 & 100 & {$[\mathrm{M}-\mathrm{HCl}-\mathrm{Cl}]^{+}$} & 257 & 257 & 100 & {$[\mathrm{M}-\mathrm{HCl}-\mathrm{Cl}]^{+}(\mathrm{d} 3)$} \\
\hline & 237.0 & 55 & {$\left[\mathrm{M}-\mathrm{HCl}-\mathrm{Cl}-\mathrm{NH}_{3}\right]^{+}$} & & 239 & 75 & {$\left[\mathrm{M}-\mathrm{DCl}-\mathrm{Cl}-\mathrm{NHD}_{2}\right]^{+}(\mathrm{d} 2)$} \\
\hline 944.0 & 615.0 & 100 & {$\left[2 \mathrm{M}-\mathrm{Cl}^{+}\right.$} & 952.0 & 623.0 & 100 & {$[2 \mathrm{M}-\mathrm{Cl}]^{+}(\mathrm{d} 8)$} \\
\hline
\end{tabular}




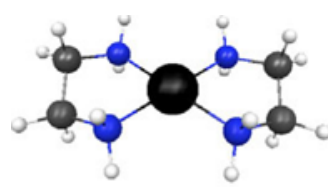

$[\mathrm{M}-2 \mathrm{Cl}+\mathrm{en}]^{2+}$

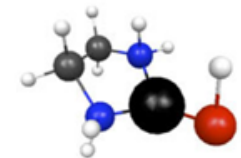

$\left[\mathrm{M}-\mathrm{HCl}-\mathrm{Cl}+\mathrm{H}_{2} \mathrm{O}\right]^{+}$

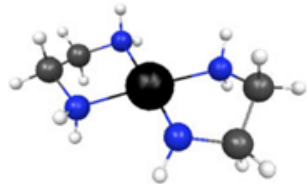

$[\mathrm{M}-\mathrm{HCl}-\mathrm{Cl}+\mathrm{en}]^{+}$

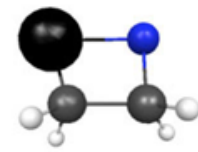

$\left[\mathrm{M}-\mathrm{HCl}-\mathrm{Cl}-\mathrm{NH}_{3}\right]^{+}$

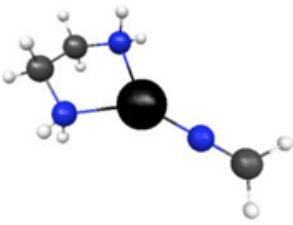

$\left[\mathrm{M}-\mathrm{HCl}-\mathrm{Cl}+\mathrm{CH}_{2}=\mathrm{NH}\right]^{+}$

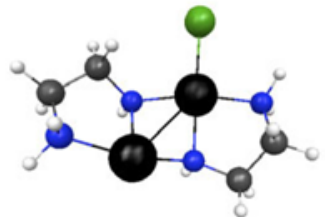

$\left[2 \mathrm{M}-2 \mathrm{HCl}-\mathrm{Cl}^{+}\right.$

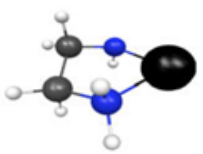

$\left[\mathrm{M}-\mathrm{HCl}-\mathrm{Cl}^{+}\right.$

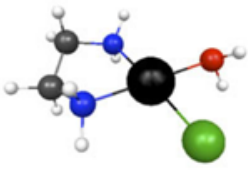

$\left[\mathrm{M}-\mathrm{Cl}+\mathrm{H}_{2} \mathrm{O}\right]^{+}$

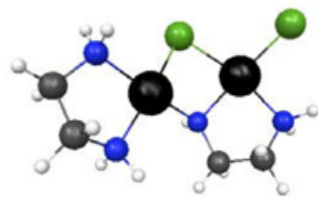

$[2 \mathrm{M}-\mathrm{HCl}-\mathrm{Cl}]^{+}$

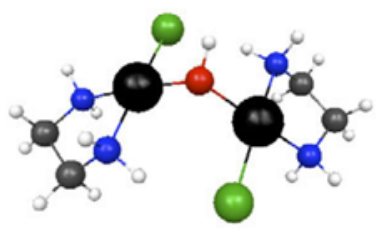

$\left[2 \mathrm{M}-\mathrm{HCl}-\mathrm{Cl}+\mathrm{H}_{2} \mathrm{O}\right]^{+}$

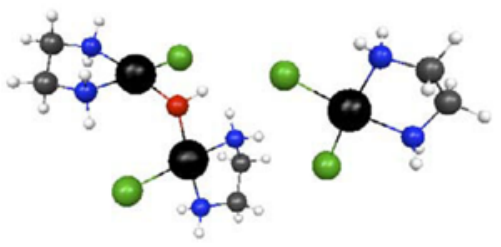

$\left[3 \mathrm{M}-\mathrm{HCl}-\mathrm{Cl}+\mathrm{H}_{2} \mathrm{O}\right]^{+}$

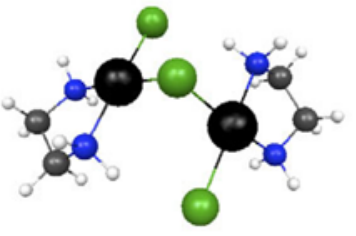

$[2 \mathrm{M}-\mathrm{Cl}]^{+}$

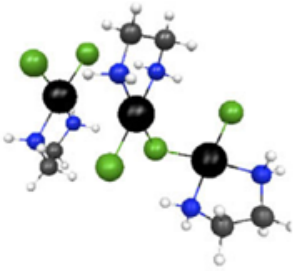

$\left[3 \mathrm{M}-\mathrm{Cl}^{+}\right.$

Figure 3. Structures of cations observed in the ESMS from dilute aqueous solutions of $\mathrm{Pt}(\mathrm{en}) \mathrm{Cl}_{2}$ calculated at the B3LYP/SBKJC[d] level of theory. Atom labels: $\mathrm{H}=$ white; $\mathrm{C}=$ gray; $\mathrm{N}=$ blue; $\mathrm{O}=$ red; $\mathrm{Cl}=$ green; and $\mathrm{Pt}=$ black .

$$
\mathrm{Pt}(\mathrm{en}) \mathrm{Cl}_{2}+\mathrm{H}_{2} \mathrm{O} \rightarrow \mathrm{Cl}^{-}+\left[\mathrm{Pt}(\mathrm{en}) \mathrm{Cl}\left(\mathrm{H}_{2} \mathrm{O}\right]^{+}\right.
$$

If the first step in the hydrolysis is assumed to proceed from a reactant complex to a product complex (eq 4), the theoretical value $\left(\Delta G_{a q}=7.8 \mathrm{kcal} / \mathrm{mol}\right)$ is within experimental error.

$$
\left[\mathrm{Pt}(\mathrm{en}) \mathrm{Cl}_{2}\right] \mathrm{H}_{2} \mathrm{O} \rightarrow\left[\mathrm{Pt}(\mathrm{en}) \mathrm{Cl}\left(\mathrm{H}_{2} \mathrm{O}\right]^{+} \mathrm{Cl}^{-}\right.
$$

The theoretical gas-phase Gibbs energy for the reaction in eq $4\left(\Delta \mathrm{G}_{\text {gas }}=8.9 \mathrm{kcal} / \mathrm{mol}\right)$ is in only slightly poorer agreement with experiment. Costa et al. have also reported theoretical gas-phase Gibbs energies at a variety of levels of theory for the reaction in eq 4, [19] where similar values were found with density functionals (B3P86 and B3PW91) closely related to that used here (B3LYP): $\Delta \mathrm{G}_{\text {gas }}=5.5$ and $6.0 \mathrm{kcal} / \mathrm{mol}$, respectively. The authors did not, however, report theoretical aqueous values.

The second step in the hydrolysis of $\mathrm{Pt}(\mathrm{en}) \mathrm{Cl}_{2}$ requires the displacement of the second chloride anion by a second water molecule. The experimental Gibbs energy for this step was determined to be $5.2 \pm 6.8$ $\mathrm{kcal} / \mathrm{mol}$ [18]. Once again, if the free energy for this step involves separated reactants and products (eq 5), the calculated value is in poor agreement with experiment $\left(\Delta \mathrm{G}_{\mathrm{aq}}=24.8 \mathrm{kcal} / \mathrm{mol}\right)$. 
Table 3. Theoretical enthalpies $(\Delta \mathrm{H})$ and Gibbs energies $(\Delta \mathrm{G})$ for the formation of observed cations at $298 \mathrm{~K}$ and $1 \mathrm{bar}$ in $\mathrm{kcal} / \mathrm{mol}$

\begin{tabular}{|c|c|c|c|c|c|}
\hline$m / z$ & $\%$ & Ion & Reaction & $\Delta \mathrm{G}_{\text {gas }}$ & $\Delta \mathrm{G}_{\mathrm{aq}}$ \\
\hline 615.0 & 100 & {$[2 \mathrm{M}-\mathrm{Cl}]^{+}$} & {$\left[\mathrm{M}-\mathrm{Cl}+\mathrm{H}_{2} \mathrm{O}\right]^{+}+\mathrm{M} \rightarrow[2 \mathrm{M}-\mathrm{Cl}]^{+}+\mathrm{H}_{2} \mathrm{O}$} & -23.6 & 5.3 \\
\hline 308.0 & 70 & {$\left[\mathrm{M}-\mathrm{Cl}+\mathrm{H}_{2} \mathrm{O}\right]^{+}$} & $\mathrm{M}+\mathrm{H}_{2} \mathrm{O} \rightarrow\left[\mathrm{M}-\mathrm{Cl}+\mathrm{H}_{2} \mathrm{O}\right]^{+}+\mathrm{Cl}^{-}$ & 118.4 & 21.8 \\
\hline 157.5 & 35 & {$[\mathrm{M}-2 \mathrm{Cl}+\mathrm{en}]^{2+}$} & {$\left[\mathrm{M}-2 \mathrm{Cl}+2 \mathrm{H}_{2} \mathrm{O}\right]^{2+}+\mathrm{en} \rightarrow[\mathrm{M}-2 \mathrm{Cl}+\mathrm{en}]^{2+}+2 \mathrm{H}_{2} \mathrm{O}$} & -55.9 & -53.2 \\
\hline 543.0 & & {$[2 \mathrm{M}-2 \mathrm{HCl}-\mathrm{Cl}]^{+}(\mathbf{X X V I})$} & {$[\mathrm{M}-\mathrm{HCl}]+[\mathrm{M}-\mathrm{HCl}-\mathrm{Cl}]^{+} \rightarrow[2 \mathrm{M}-2 \mathrm{HCl}-\mathrm{Cl}]^{+}$} & -76.3 & -58.0 \\
\hline & & {$[2 \mathrm{M}-2 \mathrm{HCl}-\mathrm{Cl}]^{+}(\mathbf{X X V})$} & {$[\mathrm{M}-\mathrm{HCl}]+[\mathrm{M}-\mathrm{HCl}-\mathrm{Cl}]^{+} \rightarrow[2 \mathrm{M}-2 \mathrm{HCl}-\mathrm{Cl}]^{+}$} & -59.8 & -40.7 \\
\hline 579.0 & 35 & $\begin{array}{l}{[2 \mathrm{M}-\mathrm{HCl}-\mathrm{Cl}]^{+}(\mathbf{X X I V})} \\
{[2 \mathrm{M}-\mathrm{HCl}-\mathrm{Cl}]^{+}(\mathbf{X X I I I})}\end{array}$ & $\begin{array}{l}{\left[\mathrm{M}-\mathrm{Cl}+\mathrm{H}_{2} \mathrm{O}\right]^{+}+[\mathrm{M}-\mathrm{HCl}] \rightarrow[2 \mathrm{M}-\mathrm{HCl}-\mathrm{Cl}]^{+}+\mathrm{H}_{2} \mathrm{O}} \\
\mathrm{M}+[\mathrm{M}-\mathrm{HCl}-\mathrm{Cl}]^{+} \rightarrow[2 \mathrm{M}-\mathrm{HCl}-\mathrm{Cl}]^{+}\end{array}$ & $\begin{array}{l}-31.4 \\
-61.5\end{array}$ & $\begin{array}{l}-28.6 \\
-25.4\end{array}$ \\
\hline 597.0 & 35 & {$\left[2 \mathrm{M}-\mathrm{HCl}-\mathrm{Cl}+\mathrm{H}_{2} \mathrm{O}\right]^{+}$} & {$\left[\mathrm{M}-\mathrm{Cl}+\mathrm{H}_{2} \mathrm{O}\right]^{+}+\left[\mathrm{M}-\mathrm{HCl}+\mathrm{H}_{2} \mathrm{O}\right] \rightarrow\left[2 \mathrm{M}-\mathrm{HCl}-\mathrm{Cl}+\mathrm{H}_{2} \mathrm{O}\right]^{+}+\mathrm{H}_{2} \mathrm{O}$} & -34.5 & -10.0 \\
\hline 314.0 & 30 & {$[\mathrm{M}-\mathrm{HCl}-\mathrm{Cl}+\mathrm{en}]^{+}$} & {$[\mathrm{M}-\mathrm{HCl}-\mathrm{Cl}]^{+}+\mathrm{en} \rightarrow[\mathrm{M}-\mathrm{HCl}-\mathrm{Cl}+\mathrm{en}]^{+}$} & -80.7 & -66.8 \\
\hline 254.0 & 15 & {$[\mathrm{M}-\mathrm{HCl}-\mathrm{Cl}]^{+}$} & {$[\mathrm{M}-2 \mathrm{Cl}]^{2+}+\mathrm{H}_{2} \mathrm{O} \rightarrow[\mathrm{M}-\mathrm{HCl}-\mathrm{Cl}]^{+}+\mathrm{H}_{3} \mathrm{O}^{+}$} & -50.7 & 31.5 \\
\hline 237.0 & 10 & {$\left[\mathrm{M}-\mathrm{HCl}-\mathrm{Cl}-\mathrm{NH}_{3}\right]^{+}$} & {$[\mathrm{M}-\mathrm{HCl}-\mathrm{Cl}]^{+} \rightarrow\left[\mathrm{M}-\mathrm{HCl}-\mathrm{Cl}-\mathrm{NH}_{3}\right]^{+}+\mathrm{NH}_{3}$} & 43.7 & 34.0 \\
\hline 283.0 & 10 & {$\left[\mathrm{M}-2 \mathrm{Cl}+\mathrm{CH}_{2} \mathrm{~N}\right]^{+}$} & {$[\mathrm{M}-2 \mathrm{Cl}+\mathrm{en}]^{2+} \rightarrow\left[\mathrm{M}-2 \mathrm{Cl}+\mathrm{CH}_{2} \mathrm{~N}\right]^{+}+\mathrm{CH}_{3} \mathrm{NH}_{3}^{+}$} & -15.9 & - \\
\hline 272.0 & 5 & {$[\mathrm{M}-2 \mathrm{Cl}+\mathrm{OH}]^{+}$} & {$\left[\mathrm{M}-2 \mathrm{Cl}+\mathrm{H}_{2} \mathrm{O}+\mathrm{OH}\right]^{+} \rightarrow[\mathrm{M}-2 \mathrm{Cl}+\mathrm{OH}]^{+}+\mathrm{H}_{2} \mathrm{O}$} & 23.2 & 13.7 \\
\hline 922.0 & & {$\left[3 \mathrm{M}-\mathrm{HCl}-\mathrm{Cl}+\mathrm{H}_{2} \mathrm{O}\right]^{+}$} & {$\left[2 \mathrm{M}-\mathrm{HCl}-\mathrm{Cl}+\mathrm{H}_{2} \mathrm{O}\right]^{+}+\mathrm{M} \rightarrow\left[3 \mathrm{M}-\mathrm{HCl}-\mathrm{Cl}+\mathrm{H}_{2} \mathrm{O}\right]^{+}$} & -14.2 & \\
\hline 944.0 & 5 & {$[3 \mathrm{M}-\mathrm{Cl}]^{+}$} & {$[2 \mathrm{M}-\mathrm{Cl}]^{+}+\mathrm{M} \rightarrow[3 \mathrm{M}-\mathrm{Cl}]^{+}$} & -16.1 & - \\
\hline
\end{tabular}

See Figure 3 for theoretical structures.

$$
\left[\mathrm{Pt}(\mathrm{en}) \mathrm{Cl}\left(\mathrm{H}_{2} \mathrm{O}\right)\right]^{+}+\mathrm{H}_{2} \mathrm{O} \rightarrow \mathrm{Cl}^{-}+\left[\mathrm{Pt}(\mathrm{en})\left(\mathrm{H}_{2} \mathrm{O}\right)_{2}\right]^{2+}
$$

If the reaction is assumed to occur between reactant and product complexes (eq 6), the theoretical aqueous value $\left(\Delta \mathrm{G}_{\mathrm{aq}}=9.5 \mathrm{kcal} / \mathrm{mol}\right)$ is within experimental error.

$$
\left[\mathrm{Pt}(\mathrm{en}) \mathrm{Cl}\left(\mathrm{H}_{2} \mathrm{O}\right)\right]^{+} \mathrm{H}_{2} \mathrm{O} \rightarrow\left[\mathrm{Pt}(\mathrm{en})\left(\mathrm{H}_{2} \mathrm{O}\right)_{2}\right]^{2+} \mathrm{Cl}^{-}
$$

The theoretical gas-phase Gibbs energy for the reaction in eq 6 is in poor agreement with experiment $\left(\Delta \mathrm{G}_{\text {gas }}=\right.$ $23.1 \mathrm{kcal} / \mathrm{mol})$. Our value is similar to that found by

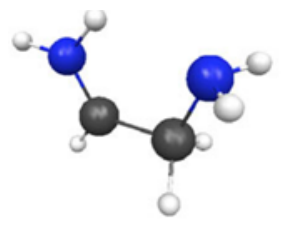

$\mathrm{H}_{2} \mathrm{NCH}_{2} \mathrm{CH}=\mathrm{NH}_{2}{ }^{+}$

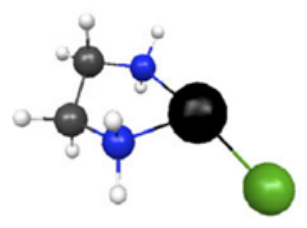

$\left[\mathrm{M}-\mathrm{Cl}^{+}\right.$

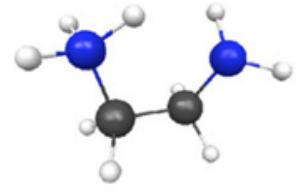

$\mathrm{H}_{2} \mathrm{NCH}_{2} \mathrm{CH}_{2} \mathrm{NH}_{3}{ }^{+}$

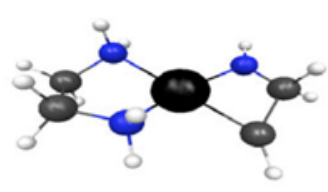

$\left[\mathrm{M}-2 \mathrm{Cl}+\text { en }-\mathrm{NH}_{4}\right]^{+}$

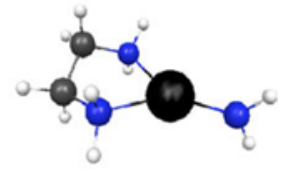

$\left[\mathrm{M}-\mathrm{HCl}-\mathrm{Cl}+\mathrm{NH}_{3}\right]^{+}$

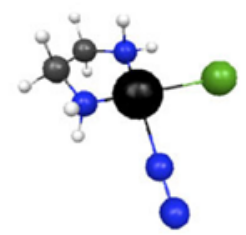

$\left[\mathrm{M}-\mathrm{Cl}+\mathrm{N}_{2}\right]^{+}$

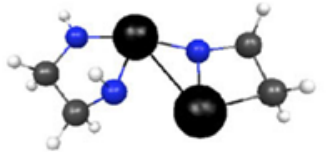

$\left[2 \mathrm{M}-3 \mathrm{HCl}-\mathrm{Cl}-\mathrm{NH}_{3}\right]^{+}$

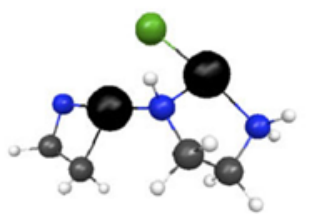

$\left[2 \mathrm{M}-2 \mathrm{HCl}-\mathrm{Cl}-\mathrm{NH}_{3}\right]^{+}$

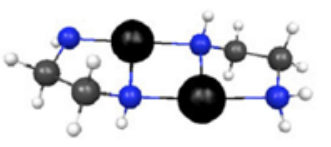

$\left[2 \mathrm{M}-3 \mathrm{HCl}-\mathrm{Cl}^{+}\right.$

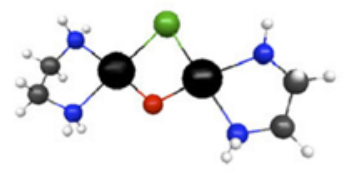

$\left[2 \mathrm{M}-2 \mathrm{HCl}-\mathrm{Cl}+\mathrm{H}_{2} \mathrm{O}\right]^{+}$

Figure 4. Structures of cations observed in the CID from dilute aqueous solutions of $\mathrm{Pt}(\mathrm{en}) \mathrm{Cl}_{2}$ calculated at the B3LYP/SBKJC[d] level of theory. Atom labels: $\mathrm{H}=$ white; $\mathrm{C}=$ gray; $N=$ blue; $\mathrm{O}=$ red; $\mathrm{Cl}=$ green; and $\mathrm{Pt}=$ black. 
Table 4. Theoretical enthalpies $(\Delta \mathrm{H})$ and Gibbs energies $(\Delta \mathrm{G})$ of observed cations formed via collision-induced dissociation (CID) at $298 \mathrm{~K}$ and $1 \mathrm{bar}$ in $\mathrm{kcal} / \mathrm{mol}$. Unless noted otherwise, parent ion is in $100 \%$ relative abundance in CID

\begin{tabular}{|c|c|c|c|c|c|}
\hline \multicolumn{2}{|r|}{ Parent } & \multicolumn{4}{|c|}{ Daughter } \\
\hline$m / z$ & Ion & $m / z$ & $\%$ & Ion & $\Delta \mathrm{G}_{\mathrm{gas}}$ \\
\hline \multirow[t]{2}{*}{615.0} & {$[2 \mathrm{M}-\mathrm{Cl}]^{+}$} & 579.0 & 100 & $\begin{array}{l}{\left[2 \mathrm{M}-\mathrm{HCl}-\mathrm{Cl}^{+}(\mathbf{X X I V})\right.} \\
{\left[2 \mathrm{M}-\mathrm{HCl}-\mathrm{Cl}^{+}(\mathbf{X X I I I})\right.}\end{array}$ & $\begin{array}{l}27.6 \\
36.6\end{array}$ \\
\hline & & 543.0 & 10 & $\begin{array}{l}{[2 \mathrm{M}-2 \mathrm{HCl}-\mathrm{Cl}]^{+}(\mathbf{X X V I})} \\
{[2 \mathrm{M}-2 \mathrm{HCl}-\mathrm{Cl}]^{+}(\mathbf{X X V})}\end{array}$ & $\begin{array}{l}57.2 \\
73.7\end{array}$ \\
\hline 308.0 & {$\left[\mathrm{M}-\mathrm{Cl}+\mathrm{H}_{2} \mathrm{O}\right]^{+}$} & $\begin{array}{l}318.0 \\
290.0\end{array}$ & $\begin{array}{l}40 \\
55\end{array}$ & $\begin{array}{l}{\left[\mathrm{M}-\mathrm{Cl}+\mathrm{N}_{2}\right]^{+}} \\
{[\mathrm{M}-\mathrm{Cl}]^{+}}\end{array}$ & $\begin{array}{l}11.3 \\
27.0\end{array}$ \\
\hline \multirow[t]{5}{*}{157.5} & {$[\mathrm{M}-2 \mathrm{Cl}+\mathrm{en}]^{2+}$} & 297.0 & 30 & {$\left[\mathrm{M}-2 \mathrm{Cl}+\text { en }-\mathrm{NH}_{4}\right]^{+}(\mathbf{X I V})$} & 14.1 \\
\hline & & 283.0 & 100 & {$\left[\mathrm{M}-\mathrm{HCl}-\mathrm{Cl}+\mathrm{CH}_{2}=\mathrm{NH}\right]^{+}$} & -15.9 \\
\hline & & 271.0 & 30 & {$\left[\mathrm{M}-\mathrm{HCl}-\mathrm{Cl}+\mathrm{NH}_{3}\right]^{+}$} & 2.6 \\
\hline & & 61.0 & 30 & $\mathrm{H}_{2} \mathrm{NCH}_{2} \mathrm{CH}_{2} \mathrm{NH}_{3}^{+}$ & 25.3 \\
\hline & & 59.0 & 55 & $\mathrm{H}_{2} \mathrm{NCH}_{2} \mathrm{CH}=\mathrm{NH}_{2}^{+}$ & 36.8 \\
\hline \multirow[t]{3}{*}{543.0} & {$[2 \mathrm{M}-2 \mathrm{HCl}-\mathrm{Cl}]^{+}(\mathbf{X X V I})$} & 526.0 & 100 & {$\left[2 \mathrm{M}-2 \mathrm{HCl}-\mathrm{Cl}-\mathrm{NH}_{3}\right]^{+}$} & 63.4 \\
\hline & & 507.0 & 35 & {$[2 \mathrm{M}-3 \mathrm{HCl}-\mathrm{Cl}]^{+}$} & 50.1 \\
\hline & & 490.0 & 10 & {$\left[2 \mathrm{M}-3 \mathrm{HCl}-\mathrm{Cl}-\mathrm{NH}_{3}\right]^{+}$} & 94.0 \\
\hline \multirow[t]{2}{*}{579.0} & {$[2 \mathrm{M}-\mathrm{HCl}-\mathrm{Cl}]^{+}(\mathbf{X X I V})$} & 543.0 & 100 & {$[2 \mathrm{M}-2 \mathrm{HCl}-\mathrm{Cl}]^{+}(\mathbf{X X V I})$} & 29.6 \\
\hline & & & & {$[2 \mathrm{M}-2 \mathrm{HCl}-\mathrm{Cl}]^{+}(\mathbf{X X V})$} & 46.1 \\
\hline \multirow[t]{3}{*}{597.0} & {$\left[2 \mathrm{M}-\mathrm{HCl}-\mathrm{Cl}+\mathrm{H}_{2} \mathrm{O}\right]^{+}(\mathbf{X X V I I I})$} & 579.0 & 100 & {$[2 \mathrm{M}-\mathrm{HCl}-\mathrm{Cl}]^{+}(\mathbf{X X I V})$} & 19.9 \\
\hline & & 561.0 & 30 & {$\left[2 \mathrm{M}-2 \mathrm{HCl}-\mathrm{Cl}+\mathrm{H}_{2} \mathrm{O}\right]^{+}$} & 34.1 \\
\hline & & 543.0 & 30 & {$[2 \mathrm{M}-2 \mathrm{HCl}-\mathrm{Cl}]^{+}(\mathbf{X X V I})$} & 49.5 \\
\hline 254.0 & {$[\mathrm{M}-\mathrm{HCl}-\mathrm{Cl}]^{+}$} & 237.0 & 55 & {$\left[\mathrm{M}-\mathrm{HCl}-\mathrm{Cl}-\mathrm{NH}_{3}\right]^{+}$} & 43.7 \\
\hline 944.0 & {$[3 \mathrm{M}-\mathrm{Cl}]^{+}$} & 615.0 & 100 & {$[2 \mathrm{M}-\mathrm{Cl}]^{+}$} & 16.1 \\
\hline
\end{tabular}

See Figure 4 for theoretical structures.

Costa et al. : $\Delta \mathrm{G}_{\text {gas }}=22.0$ and $24.5 \mathrm{kcal} / \mathrm{mol}$ [19]. Costa et al. also calculated an aqueous Gibbs energy for the reaction in eq 6 [20]. Their best agreement with experiment was found using second-order Möller-Plesset (MP2) theory $\left(\Delta \mathrm{G}_{\mathrm{aq}}=16.5 \mathrm{kcal} / \mathrm{mol}\right)$ [21]. Given the similarity between our and their gas-phase, this discrepancy is probably attributable to differences in solvation models or (possibly) intermediates.

It is possible to conclude from the foregoing theoretical results, which reproduce the experimental thermodynamics for hydrolysis, that the level of theory selected for the current study of Pt(en) $\mathrm{Cl}_{2}$ is satisfactory.

\section{Monometallic Cations}

Electrospray mass spectrometry (ESMS) was used to establish the identities of these hydrolysis products. It was realized that some of the observed cations may be simply an artifacts of the ESMS process; i.e., the observed cations may not truly be in solution [22]. If the fidelity of the ESMS method could be conclusively demonstrated, it would represent a powerful tool in analyzing complex solutions. For convenience, the observed cations have been divided into three groups based upon the number of $\mathrm{Pt}$ atoms contained in the structure: mono-, bi-, and trimetallic cations.

$\left[\mathrm{M}-\mathrm{Cl}+\mathrm{H}_{2} \mathrm{O}\right]^{+}$. Upon dissolving the parent $\mathrm{Pt}(\mathrm{en}) \mathrm{Cl}_{2}$ compound $(\mathbf{V})$ in $\mathrm{H}_{2} \mathrm{O}$, two hydrolysis products are predicted to be formed: $\left[\mathrm{M}-\mathrm{Cl}+\mathrm{H}_{2} \mathrm{O}\right]^{+}(\mathbf{V I})$ and $[\mathrm{M}-2 \mathrm{Cl}+$ $\left.2 \mathrm{H}_{2} \mathrm{O}\right]^{2+}(\mathrm{VII})$. Evidence for the presence of the $[\mathrm{M}-\mathrm{Cl}+$ $\left.\mathrm{H}_{2} \mathrm{O}\right]^{+}$ion was found in the ESMS, where an ion with a $\mathrm{m} / \mathrm{z}$ of 308.0 was detected in a relative abundance of $70 \%$. A cation with the appropriate $\mathrm{m} / \mathrm{z} 145.5$ was not detected for the $\left[\mathrm{M}-2 \mathrm{Cl}+2 \mathrm{H}_{2} \mathrm{O}\right]^{2+}$ ion. The inability to detect this ion may be due to its reactivity in solution.

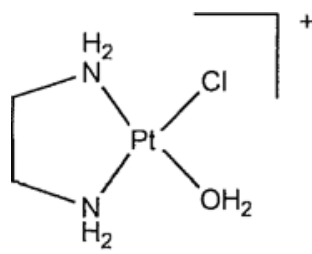

VI

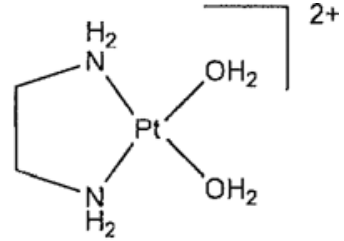

VII
Further evidence for the existence of the $[\mathrm{M}-\mathrm{Cl}+$ $\left.\mathrm{H}_{2} \mathrm{O}\right]^{+}$ion was found in the ESMS spectrum obtained from dissolving the parent compound in $\mathrm{D}_{2} \mathrm{O}$. This spectrum revealed the presence of a cation with a $\mathrm{m} / \mathrm{z}$ of 314.0 in $55 \%$ relative abundance. This cation is consistent with four hydrogen-deuterium exchanges (presumably at the more acidic amino groups) and coordination with a $\mathrm{D}_{2} \mathrm{O}$ molecule. This would lead to an increase in $6 \mathrm{u}$ in the $\mathrm{m} / \mathrm{z}$ over that seen for the hydrogen analog.

Collision-induced dissociation (CID) of the $\mathrm{M}-\mathrm{Cl}+$ $\mathrm{H}_{2} \mathrm{O}^{+}$ion yields two fragment ions: $\mathrm{m} / z 290.0$ (55\%) and $\mathrm{m} / \mathrm{z} 318.0(40 \%)$. The first of these fragment ions is consistent with the loss of $\mathrm{H}_{2} \mathrm{O}$ to yield the $[\mathrm{M}-\mathrm{Cl}]^{+}$ion (VIII). The second fragment ion actually represents an increase in the $\mathrm{m} / \mathrm{z}$, which is highly unusual. This fragment ion may simply result from the clustering of the $[\mathrm{M}-\mathrm{Cl}]^{+}$fragment ion with background $\mathrm{N}_{2},[\mathrm{M}-\mathrm{Cl}+$ 
$\left.\mathrm{N}_{2}\right]^{+}$(IX). When CID was performed upon the deuterium counterpart, two similar fragment ions are also seen: $\mathrm{m} / \mathrm{z}$ $294.0(35 \%)$ and $\mathrm{m} / \mathrm{z} 322.0$ (75\%). These results are consistent with the above assignments for the $\mathrm{H}_{2} \mathrm{O}$ species, i.e., $[\mathrm{M}-\mathrm{Cl}]^{+}(\mathrm{d} 4)$ and $\left[\mathrm{M}-\mathrm{Cl}+\mathrm{N}_{2}\right]^{+}(\mathrm{d} 4)$, respectively. It should be noted that such clustering reactions in ion traps are very rare; before such a conclusive assignment can be made, high-resolution MS data would required.

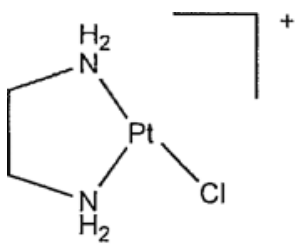

VIII

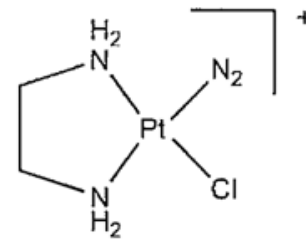

IX
Theoretical calculations predict that the $\left[\mathrm{M}-\mathrm{Cl}+\mathrm{H}_{2} \mathrm{O}\right]^{+}$ ion would possess a four-coordinate, square-planar geometry about the Pt atom. The substitution of a chloride anion by a water molecule (eq 3 ) is highly endergonic in the gas-phase $\left(\Delta \mathrm{G}_{\mathrm{gas}}=118.4 \mathrm{kcal} / \mathrm{mol}\right)$, while the reaction in aqueous solution is mildly endergonic $\left(\Delta \mathrm{G}_{\mathrm{aq}}=21.8 \mathrm{kcal} / \mathrm{mol}\right)$. An idea of the intrinsic strength of the $\mathrm{Pt}_{-} \mathrm{OH}_{2}$ bond in the $[\mathrm{M}-$ $\mathrm{Cl}+\mathrm{H}_{2} \mathrm{Ol}^{+}$ion can be gained from calculating the minimum Gibbs energy for the loss of water from the $[\mathrm{M}-\mathrm{Cl}+$ $\left.\mathrm{H}_{2} \mathrm{O}\right]^{+}$ion $\left(\Delta \mathrm{G}_{\text {gas }}=27.0 \mathrm{kcal} / \mathrm{mol}\right)$. The reaction is slightly less endergonic in aqueous solution $\left(\Delta \mathrm{G}_{\mathrm{aq}}=14.0 \mathrm{kcal} / \mathrm{mol}\right)$. The results clearly demonstrate that, while $\mathrm{H}_{2} \mathrm{O}$ should freely exchange in $\left[\mathrm{M}-\mathrm{Cl}+\mathrm{H}_{2} \mathrm{O}\right]^{+}$ion, the Pt atom wants to retain a four-coordinate valence.

$[\mathrm{M}-2 \mathrm{Cl}+e n]^{2+}$. A cation was observed in the $\mathrm{H}_{2} \mathrm{O}$ ESMS with a $\mathrm{m} / \mathrm{z}$ of 157.5 in a relative abundance of $35 \%$. Half $\mathbf{u ~} \mathrm{m} / \mathrm{z}$ are indicative of doubly charged ions. The spectrum also clearly shows the absence of a $\mathrm{Cl}$ atom in this cation. It is, therefore, postulated that this cation contains two ethylenediamine (en) ligands coordinated to the $\mathrm{Pt}$ atom, i.e., $[\mathrm{M}-2 \mathrm{Cl}+\mathrm{en}]^{2+}(\mathbf{X})$.

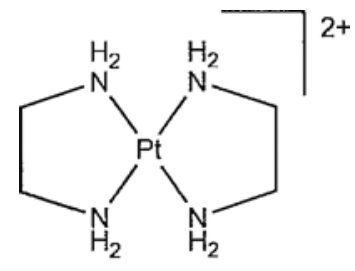

\section{$\mathrm{x}$}

This structural assignment is further corroborated by the ESMS derived from the $\mathrm{D}_{2} \mathrm{O}$ solution, where an ion with a $\mathrm{m} / \mathrm{z}$ of 161.5 was observed in a $25 \%$ relative abundance. This increase of $4 \mathrm{u}$ corresponds to eight hydrogen-deuterium exchanges presumably at the four amino groups.

Subjecting the $[\mathrm{M}-2 \mathrm{Cl}+\mathrm{en}]^{2+}$ ion to CID yields five fragment ions. The $\mathrm{m} / \mathrm{z} 61.0$ ion $(30 \%)$ corresponds

to a protonated en, $\mathrm{H}_{2} \mathrm{NCH}_{2} \mathrm{CH}_{2} \mathrm{NH}_{3}{ }^{+}$, presumably formed from the loss of en followed by proton transfer. Proton transfer could occur from a number of sources, e.g., the $[\mathrm{M}-2 \mathrm{Cl}+\text { en }]^{2+}$ ion (eq 7).

$$
\begin{aligned}
& {[\mathrm{M}-2 \mathrm{Cl}+\text { en }]^{2+}} \\
& \quad+\mathrm{H}_{2} \mathrm{NCH}_{2} \mathrm{CH}_{2} \mathrm{NH}_{2} \rightarrow \mathrm{H}_{2} \mathrm{NCH}_{2} \mathrm{CH}_{2} \mathrm{NH}_{3}^{+} \\
& \quad+[\mathrm{M}-\mathrm{HCl}-\mathrm{Cl}+\text { en }]^{+}
\end{aligned}
$$

The theoretical Gibbs energy for this proton transfer is -55.5 $\mathrm{kcal} / \mathrm{mol}$ in the gas-phase, and the reaction is, therefore, quite possible. When the Gibbs energy required to produce free en is also considered, the overall reaction is calculated to be endergonic $\left(\Delta \mathrm{G}_{\mathrm{gas}}=36.9 \mathrm{kcal} / \mathrm{mol}\right)$. A $m / z 59.0$ fragment ion is also seen in $55 \%$ relative abundance. This corresponds to the loss of $\mathrm{H}_{2}$ from a protonated, ethylenediamine, presumably through a second CID process.

A fragment ion was also observed with a $\mathrm{m} / \mathrm{z}$ of 271.0 in $30 \%$ relative abundance, which is consistent with a $[\mathrm{M}-$ $\left.\mathrm{HCl}-\mathrm{Cl}+\mathrm{NH}_{3}\right]^{+}$ion. Two possible isomers (XI and XII) exist for this cation that differ with respect to a single $\mathrm{H}$ atom. Theory predicts that XI is more stable than XII by 1.9 $\mathrm{kcal} / \mathrm{mol}$.

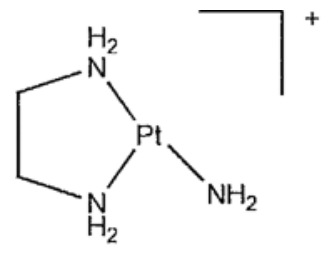

$\mathbf{X I}$

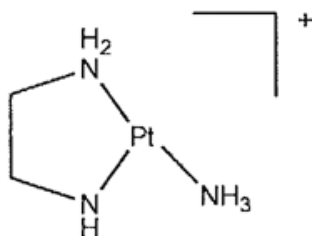

XII

This CID product could be formed simply via a clustering reaction between $[\mathrm{M}-\mathrm{HCl}-\mathrm{Cl}]^{+}$and $\mathrm{NH}_{3}$ followed by an intramolecular proton transfer. The theoretical Gibbs energy for this reaction is -47.8 $\mathrm{kcal} / \mathrm{mol}$, and the overall Gibbs energy for the formation of the $\mathrm{m} / \mathrm{z} 271.0$ ion is calculated to be $4.5 \mathrm{kcal} / \mathrm{mol}$.

A fragment ion detected with a $\mathrm{m} / \mathrm{z}$ of 283.0 in $100 \%$ relative abundance also offer evidence for the presence of the $[\mathrm{M}-\mathrm{HCl}-\mathrm{Cl}]^{+}$ion. Calculations suggest that this ion is formed from the clustering of the $[\mathrm{M}-\mathrm{HCl}-\mathrm{Cl}]^{+}$ ion with methyl imine $\left(\mathrm{CH}_{2}=\mathrm{NH}\right)$ to yield the [M $\left.\mathrm{HCl}-\mathrm{Cl}+\mathrm{CH}_{2}=\mathrm{NH}\right]^{+}$ion. Once again, two isomers are possible for this ion that differ with respect to a single $\mathrm{H}$ atom (XIII and XIV).

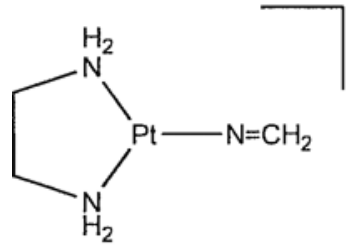

XIII

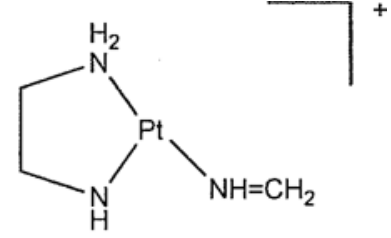


Ion XIII is calculated to be more stable than ion XIV by $9.8 \mathrm{kcal} / \mathrm{mol}$. This clustering reaction leading to the formation of XIII is predicted to be energetically favorable $\left(\Delta \mathrm{G}_{\text {gas }}=-59.2 \mathrm{kcal} / \mathrm{mol}\right)$. Because of the exergonicity of this reaction, the overall reaction for the formation of the $\mathrm{m} / \mathrm{z} 283.0$ fragment ion is also favorable $\left(\Delta \mathrm{G}_{\text {gas }}=-15.9 \mathrm{kcal} / \mathrm{mol}\right)$.

The presence of fragment ions with $\mathrm{NH}_{3}$ and $\mathrm{CH}_{2}=$ $\mathrm{NH}$ requires the fragmentation of an en group. Evidence for this is seen in the fragment ion detected with a $\mathrm{m} / \mathrm{z}$ of 297.0 in 30\% relative abundance. This $\mathrm{m} / \mathrm{z}$ is in keeping with a $\left[\mathrm{M}-2 \mathrm{Cl}+\text { en }-\mathrm{NH}_{4}\right]^{+}$ion $(\mathbf{X V})$.

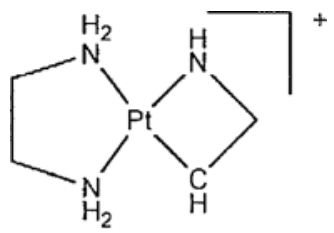

\section{XV}

The formation of this cation, which is moderately endergonic $\left(\Delta \mathrm{G}_{\mathrm{gas}}=22.7 \mathrm{kcal} / \mathrm{mol}\right)$, could be the source of the $\mathrm{NH}_{3}$ found in the $\mathrm{m} / \mathrm{z} 271.0$ cation. The methyl imine used in the formation of the $\mathrm{m} / \mathrm{z} 283.0$ ion would necessitate the loss of $\mathrm{CH}_{3} \mathrm{NH}_{2}$ from an en group. No direct evidence for any ion formed from the clustering of $\mathrm{CH}_{3} \mathrm{NH}_{2}$ was seen (e.g., $[\mathrm{M}-\mathrm{HCl}-\mathrm{Cl}+$ $\left.\mathrm{CH}_{3} \mathrm{NH}_{2}\right]^{+}, m / z 285.0$ ), but such a species may simply not be well resolved in the CID; i.e., the signal associated with a $\mathrm{m} / \mathrm{z} 285.0$ ion may overlap that of the $\mathrm{m} / \mathrm{z}$ 283.0 ion.

When CID is performed upon the deuterated [M $2 \mathrm{Cl}+\mathrm{en}^{2+}$ ion, fragment ions entirely consistent with the above species are seen with only minor differences in their relative abundances: $\mathrm{m} / \mathrm{z} 63.0$ (60\%), $66.0(5 \%), 277.0(25 \%), 287.0(100 \%)$, and 301.0 $(40 \%)$. These fragment ions exhibit, therefore, four, five, six, four, and four hydrogen-deuterium exchanges, respectively.

To form the $[\mathrm{M}-2 \mathrm{Cl}+\mathrm{en}]^{2+}$ ion, free en must be present (in solution or the gas-phase). Direct evidence for free en is not possible in the MS experiments as it is not charged and, therefore, not detectable. Direct hydrolysis of the parent compound (eq 8) is calculated to be endergonic $\left(\Delta \mathrm{G}_{\mathrm{aq}}=49.3 \mathrm{kcal} / \mathrm{mol}\right)$.

$$
\mathrm{Pt}(\mathrm{en}) \mathrm{Cl}_{2}+2 \mathrm{H}_{2} \mathrm{O} \rightarrow\left[\mathrm{M}-\mathrm{en}+\mathrm{H}_{2} \mathrm{O}\right]+\text { en }
$$

It is also possible that free en could be produced via attack by chloride anions on the parent compound (eq 9).

$$
\mathrm{Pt}(\mathrm{en}) \mathrm{Cl}_{2}+2 \mathrm{Cl}^{-} \rightarrow\left[\mathrm{PtCl}_{4}\right]^{2-}+\text { en }
$$

This reaction is calculated to be less endergonic than that for direct hydrolysis $\left(\Delta \mathrm{G}_{\mathrm{aq}}=17.1 \mathrm{kcal} / \mathrm{mol}\right)$. Once free en is formed in aqueous solution, the $[\mathrm{M}-2 \mathrm{Cl}+$ $\mathrm{en}^{2+}$ ion could be formed by three related reactions. (eqs 10-12).

$$
\begin{aligned}
& \mathrm{Pt}(\text { en }) \mathrm{Cl}_{2}+\text { en } \rightarrow[\mathrm{M}-2 \mathrm{Cl}+\text { en }]^{2+}+2 \mathrm{Cl}^{-} \\
& \left.\quad \mathrm{M}-\mathrm{Cl}+\mathrm{H}_{2} \mathrm{O}\right]^{+}+\text {en } \rightarrow\left[\mathrm{M}-2 \mathrm{Cl}+\mathrm{en}^{2+}+\mathrm{Cl}^{-}\right. \\
& \quad+\mathrm{H}_{2} \mathrm{O} \\
& {\left[\mathrm{M}-2 \mathrm{Cl}+2 \mathrm{H}_{2} \mathrm{O}\right]^{2+}+\text { en } \rightarrow[\mathrm{M}-2 \mathrm{Cl}+\text { en }]^{2+}+2 \mathrm{H}_{2} \mathrm{O}}
\end{aligned}
$$

All three reactions are calculated to be exergonic: $\Delta G_{\text {aq }}$ $(10)=-6.7, \Delta \mathrm{G}_{\mathrm{aq}}(11)=-22.0$, and $\Delta \mathrm{G}_{\mathrm{aq}}(12)=-53.2$ $\mathrm{kcal} / \mathrm{mol}$.

$[\mathrm{M}-\mathrm{HCl}-\mathrm{Cl}+\mathrm{en}]^{+},[\mathrm{M}-\mathrm{HCl}-\mathrm{Cl}]^{+}$, and $[\mathrm{M}-$ $\left.\mathrm{HCl}-\mathrm{Cl}+\mathrm{H}_{2} \mathrm{O}\right]^{+}$. A cation closely related to the $[\mathrm{M}-$ $2 \mathrm{Cl}+\mathrm{en}]^{2+}$ ion was detected in the $\mathrm{H}_{2} \mathrm{O}$ ESMS with a $\mathrm{m} / \mathrm{z}$ of 314.0 in a relative abundance of $30 \%$. This $\mathrm{m} / \mathrm{z}$ increases by $7 \mathrm{u}$ in the $\mathrm{D}_{2} \mathrm{O}$ ESMS $(\mathrm{m} / \mathrm{z} 321.0)$, which would correspond to seven hydrogen-deuterium exchanges. As neither spectra exhibit the presence of $\mathrm{Cl}$ atoms, the assignment of $[\mathrm{M}-\mathrm{HCl}-\mathrm{Cl}+\mathrm{en}]^{+}(\mathbf{X V I})$ can be made for this cation. It was not possible to further corroborate this assignment via CID as the signals associated with these cations were not isolable due to their overlap with other signals in their respective spectra.

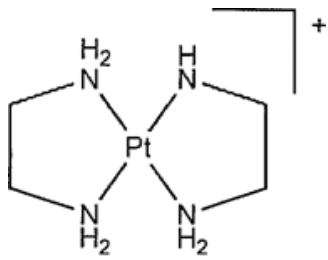

\section{XVI}

One possible mechanism for the formation of the $[\mathrm{M}-\mathrm{HCl}-\mathrm{Cl}+\mathrm{en}]^{+}$ion is simple deprotonation of the $[\mathrm{M}-2 \mathrm{Cl}+\mathrm{en}]^{2+}$ ion at one of the amino positions (eq 13).

$$
[\mathrm{M}-2 \mathrm{Cl}+\mathrm{en}]^{2+}+\mathrm{B} \rightarrow \mathrm{BH}^{+}+[\mathrm{M}-\mathrm{HCl}-\mathrm{Cl}+\text { en }]^{+}
$$

In aqueous solution, $\mathrm{H}_{2} \mathrm{O}$ is not basic enough to affect the deprotonation $\left(\Delta \mathrm{G}_{\mathrm{aq}}(13)=54.3 \mathrm{kcal} / \mathrm{mol}\right.$ when $\mathrm{B}=$ $\mathrm{H}_{2} \mathrm{O}$ ). This deprotonation is, however, more favorable in the gas-phase $\left(\Delta \mathrm{G}_{\text {gas }}(13)=8.2 \mathrm{kcal} / \mathrm{mol}\right.$ when $\mathrm{B}=$ $\mathrm{H}_{2} \mathrm{O}$ ). It is also possible that another species could serve as the base, e.g., ethylenediamine. The gas-phase Gibbs energy for the reaction in eq 13 is $-55.5 \mathrm{kcal} / \mathrm{mol}$ when $\mathrm{B}=$ en. The deprotonation is, however, mildly endergonic in aqueous solution $\left(\Delta \mathrm{G}_{\mathrm{aq}}(13)=12.9 \mathrm{kcal} / \mathrm{mol}\right.$ when $B=$ en).

A more intriguing possibility for the formation of the $\left[\mathrm{M}-\mathrm{HCl}-\mathrm{Cl}+\mathrm{en}^{+}\right.$ion is due to clustering (eq 14). 


$$
[\mathrm{M}-\mathrm{HCl}-\mathrm{Cl}]^{+}+\text {en } \rightarrow[\mathrm{M}-\mathrm{HCl}-\mathrm{Cl}+\mathrm{en}]^{+}
$$

Such a reaction would require the presence of the $[\mathrm{M}-$ $\mathrm{HCl}-\mathrm{Cl}]^{+}$ion $(\mathbf{X V I I})$. Direct evidence for this cation is seen in the ESMS obtained from the $\mathrm{H}_{2} \mathrm{O}$ solution, where a cation with a $\mathrm{m} / \mathrm{z}$ of 254.0 was observed in $15 \%$ relative abundance. When the ESMS from the $\mathrm{D}_{2} \mathrm{O}$ solution is examined, a cation with a $\mathrm{m} / \mathrm{z}$ of 257.0, corresponding to thee hydrogen-deuterium exchanges, is detected in $10 \%$ relative abundance.

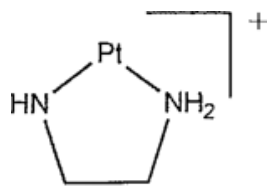

\section{XVII}

Evidence for the related monoaqua $[\mathrm{M}-\mathrm{HCl}-\mathrm{Cl}+$ $\left.\mathrm{H}_{2} \mathrm{O}\right]^{+}$cation (XVIII) is also seen in the respective $\mathrm{H}_{2} \mathrm{O}$ and $\mathrm{D}_{2} \mathrm{O}$ solution $\left(\mathrm{H}_{2} \mathrm{O}: \mathrm{m} / \mathrm{z} 272.0,5 \% ; \mathrm{D}_{2} \mathrm{O}: \mathrm{m} / \mathrm{z} 277.0\right.$, $5 \%)$. It is interesting, however, that no evidence for the diaqua cation, $\left[\mathrm{M}-\mathrm{HCl}-\mathrm{Cl}+2 \mathrm{H}_{2} \mathrm{O}\right]^{+}$(XIX), was found.

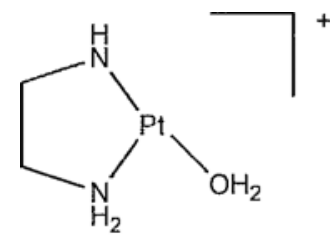

XVIII

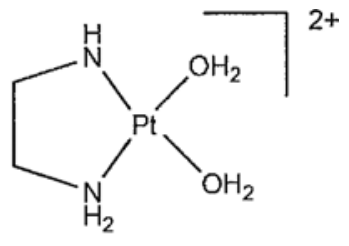

XIX
The Gibbs energy for the formation of the [M $\mathrm{HCl}-\mathrm{Cl}+\mathrm{en}]^{+}$ion via the reaction in eq 14 is favorable: $\Delta \mathrm{G}_{\mathrm{gas}}=-80.7$ and $\Delta \mathrm{G}_{\mathrm{aq}}=-66.8 \mathrm{kcal} /$ mol. While possibly this cation is formed by simple deprotonation of the $[\mathrm{M}-2 \mathrm{Cl}+\mathrm{en}]^{2+}$ ion, thermodynamic arguments suggest that the clustering reaction is more likely.

$\left[\mathrm{M}-\mathrm{HCl}-\mathrm{Cl}-\mathrm{NH}_{3}\right]^{+}$and $\left[\mathrm{M}-\mathrm{HCl}-\mathrm{Cl}+\mathrm{CH}_{2}=\right.$ $\mathrm{NH}]^{+}$. When the $[\mathrm{M}-\mathrm{HCl}-\mathrm{Cl}]^{+}$ion is subjected to CID, a single fragment ion with a $\mathrm{m} / \mathrm{z}$ of 237.0 in $55 \%$ relative abundance is detected. This fragment ion corresponds to the loss of $17 \mathrm{u}$; i.e., $\mathrm{NH}_{3}$. It is postulated based upon theoretical considerations that this ion has four-member ring structure $(\mathbf{X X})$. The theoretical Gibbs energy corresponding to the CID process amounts to only $43.7 \mathrm{kcal} /$ mol.

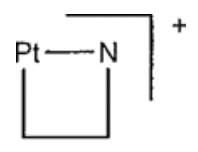

Collision-induced dissociation on the deuterated counterpart yields a $\mathrm{m} / \mathrm{z} 239.0$ fragment ion in $75 \%$ relative abundance. This increase of $2 \mathrm{u}$ would demand two hydrogen-deuterium exchanges. Given the proposed structure for this ion, the two exchanges would have to occur at one or both of the methylene positions. The methylene group that is adjacent to the $\mathrm{N}$ atom is calculated to be the more acidic position. Proton transfer between this cation and $\mathrm{H}_{2} \mathrm{O}$ (eq 15) is only slightly endergonic in the gas-phase $\left(\Delta \mathrm{G}_{\text {gas }}=8.1\right.$ $\mathrm{kcal} / \mathrm{mol})$.

$$
\begin{aligned}
& {\left[\mathrm{M}-\mathrm{HCl}-\mathrm{Cl}-\mathrm{NH}_{3}\right]^{+}+\mathrm{H}_{2} \mathrm{O} \rightarrow \mathrm{H}_{3} \mathrm{O}^{+}} \\
& \quad+\left[\mathrm{M}-\mathrm{HCl}-\mathrm{Cl}-\mathrm{NH}_{4}\right]
\end{aligned}
$$

The reaction is, however, calculated to be actually favorable in aqueous solution $\left(\Delta \mathrm{G}_{\mathrm{aq}}=-6.9 \mathrm{kcal} /\right.$ mol). Direct evidence for the $\left[\mathrm{M}-\mathrm{HCl}-\mathrm{Cl}-\mathrm{NH}_{3}\right]^{+}$ ion is also seen in the ESMS obtained from the $\mathrm{H}_{2} \mathrm{O}$ solution, where a cation with a $\mathrm{m} / \mathrm{z}$ of 237.0 was detected in $10 \%$ relative abundance. The corresponding ion derived from the $\mathrm{D}_{2} \mathrm{O}$ solution shows a $2 \mathrm{u}$ increase in its $\mathrm{m} / \mathrm{z}$ and was found in only $5 \%$ relative abundance.

Another intriguing ion observed in the ESMS derived from the $\mathrm{H}_{2} \mathrm{O}$ solution has a $\mathrm{m} / \mathrm{z}$ of $283.0(10 \%)$. This cation is consistent with a $\left[\mathrm{M}-\mathrm{HCl}-\mathrm{Cl}+\mathrm{CH}_{2}=\right.$ $\mathrm{NH}]^{+}$stoichiometry. A structure for this ion consisting of a trivalent $\mathrm{Pt}$ atom coordinated to an en and a $\mathrm{CH} 2=\mathrm{N}^{-}$anion is proposed $(\mathbf{X X I})$. Such an ion should exhibit four hydrogen-deuterium exchanges at the two amino groups, and this is what is seen in the ESMS obtained from the $\mathrm{D}_{2} \mathrm{O}$ solution $(\mathrm{m} / \mathrm{z} 287.0,5 \%)$.

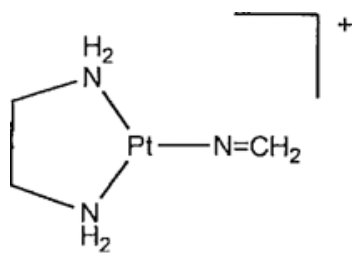

\section{XXI}

As was noted above, this ion was also likely a fragment ion in the CID of the $[\mathrm{M}-2 \mathrm{Cl}+\mathrm{en}]^{2+}$ parent ion.

Both of these ions, $\mathbf{X X}$ and $\mathbf{X X I}$, show that the en group is not particularly stable with respect to fragmentation, especially when the Pt atom in not four-coordinate. These results are reminiscent of the catalytic properties of $\mathrm{Pt}$ metal surfaces, whose catalytic capabilities are largely derived from the incomplete valences of surface atoms [23].

\section{Bimetallic Cations $[2 \mathrm{M}-\mathrm{Cl}]^{+}$}

The base peak ( $100 \%$ relative abundance) was found to correspond to a cation with a $\mathrm{m} / \mathrm{z}$ of 615.0 in the ESMS 
obtained from the $\mathrm{H}_{2} \mathrm{O}$ solution. This cation is consistent with the clustering of the $\mathrm{Pt}(\mathrm{en}) \mathrm{Cl}_{2}$ parent $(\mathbf{V})$ and a $[\mathrm{M}-\mathrm{Cl}]^{+}$ion (VIII). While such a clustering reaction is possible, no direct evidence for the $[\mathrm{M}-\mathrm{Cl}]^{+}$ion was observed in the ESMS spectra. It is far more likely that the $m / z 615.0$ cation is formed from the reaction of the $\mathrm{Pt}(\mathrm{en}) \mathrm{Cl}_{2}$ neutral with the $\left[\mathrm{M}-\mathrm{Cl}+\mathrm{H}_{2} \mathrm{O}\right]^{+}$ion $(\mathbf{V I})$ to form the observed $[2 \mathrm{M}-\mathrm{Cl}]^{+}$ion (XXII) via the reaction in eq 16.

$$
\mathrm{M}+\left[\mathrm{M}-\mathrm{Cl}+\mathrm{H}_{2} \mathrm{O}\right]^{+} \rightarrow[2 \mathrm{M}-\mathrm{Cl}]^{+}+\mathrm{H}_{2} \mathrm{O}
$$

Theory predicts the lowest energy structure for this ion to have a bridging $(\mu)$ chloride anion, which permits both $\mathrm{Pt}$ atoms to maintain four-coordinate, squareplanar geometries. It also suggests that this reaction is favorable in the gas-phase $\left(\Delta \mathrm{G}_{\text {gas }}=-23.6 \mathrm{kcal} / \mathrm{mol}\right)$ and only slightly endergonic in solution $\left(\Delta \mathrm{G}_{\mathrm{aq}}=5.3\right.$ $\mathrm{kcal} / \mathrm{mol}$ ). These results offer further evidence for the partial hydrolysis of the parent compound. They also suggest that dimeric species may be present in solution, although it cannot be ruled out that these species are merely due to concentration effects (i.e., an artifact of the ESMS process).

The ESMS obtained from the $\mathrm{D}_{2} \mathrm{O}$ solution reveals the presence of a cation with a $\mathrm{m} / \mathrm{z}$ of 623.0 in $100 \%$ abundance. This represents an $8 \mathrm{u}$ increase in the $m / z$ of the $\mathrm{H}_{2} \mathrm{O}$ analog, which is consistent with the structural assignment given eight hydrogen-deuterium exchanges at the four amino groups.

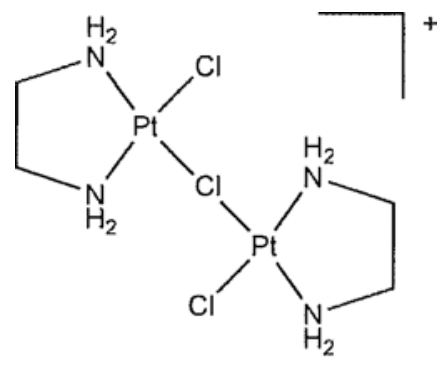

\section{XXII}

An additional pathway for the formation of the [2M $\mathrm{Cl}^{+}$ion was also investigated theoretically. Here, two $\mathrm{Pt}(\mathrm{en}) \mathrm{Cl}_{2}$ neutral molecules first cluster to form a dimeric structure (eq 17), and chloride is then lost to yield the observed cation (eq 18).

$$
\begin{aligned}
& \mathrm{M}+\mathrm{M} \rightarrow \mathrm{M}_{2} \\
& \mathrm{M}_{2} \rightarrow[2 \mathrm{M}-\mathrm{Cl}]^{+}+\mathrm{Cl}^{-}
\end{aligned}
$$

While this reaction is predicted to be highly endergonic in the gas-phase $\left(\Delta \mathrm{G}_{\text {gas }}=106.2 \mathrm{kcal} / \mathrm{mol}\right)$, it is found to be theoretically possible in solution $\left(\Delta \mathrm{G}_{\mathrm{aq}}=0.2 \mathrm{kcal} /\right.$ $\mathrm{mol})$. Under the conditions of high concentration present in the electrospray experiment, such a pathway may, therefore, be viable.
When the $[2 \mathrm{M}-\mathrm{Cl}]^{+}$ion is subjected to CID, two fragment ions are produced: $\mathrm{m} / \mathrm{z} 579.0(100 \%)$ and $\mathrm{m} / \mathrm{z}$ $543.0(10 \%)$. These fragment ions correspond to the sequential loss of one and two equivalents of $\mathrm{HCl}$, respectively. As was noted in our earlier investigations [6], this is a common fragmentation mechanism for these types of species. When the deuterated analog is subjected to CID, again two fragment ions are formed: $m / z 586.0(100 \%)$ and $m / z 550.0(10 \%)$. These fragment ions are consistent with the loss of one and two DCl molecules, respectively, from the fully deuterated $[2 \mathrm{M}-\mathrm{Cl}]^{+}$ion.

Theory offers two possible structures for the $\mathrm{m} / \mathrm{z}$ 579.0 ion: the first structure has two chloride ions bridging the Pt atoms with the loss of a proton from one of the amino groups (XXIII), while the second structure has both chloride and deprotonated amino bridges between the Pt atoms (XXIV).

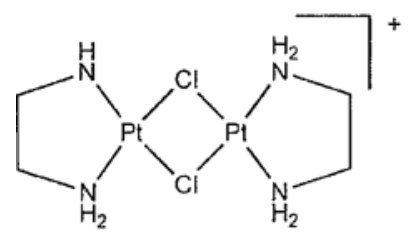

XXIII

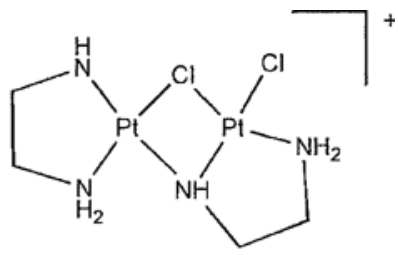

XXIV
Cation XXIV is calculated to be the lower energy isomer by $9.0 \mathrm{kcal} / \mathrm{mol}$. The Gibbs energy required to affect the loss of the first $\mathrm{HCl}$ molecule from the parent ion to form the fragment ion XXIV amounts to only 27.6 $\mathrm{kcal} / \mathrm{mol}$. This Gibbs energy is somewhat larger for the comparable reaction leading to cation XXIII $\left(\Delta G_{\text {gas }}=\right.$ $36.6 \mathrm{kcal} / \mathrm{mol})$.

The loss of the second $\mathrm{HCl}$ molecule, resulting in a $\mathrm{m} / \mathrm{z} 543.0$ fragment ion, also leads to two possible cationic isomers. In the first of these ions, one of the bridges between the $\mathrm{Pt}$ atoms is a chloride anion (XXV), while in the second, the chloride anion is only attached to one of the Pt atoms (XXVI).

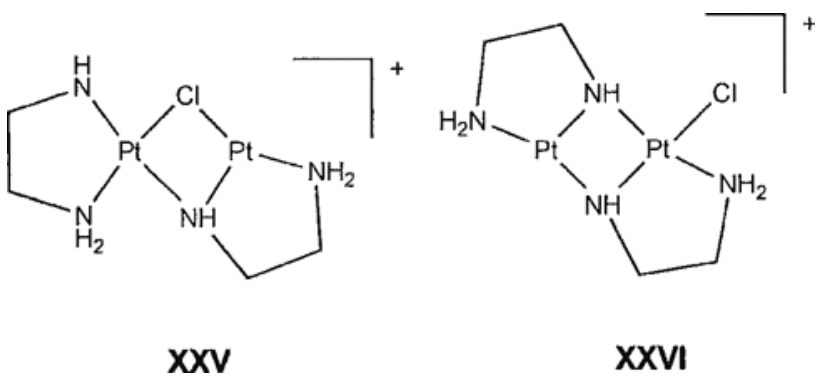

Cation XXVI is the lower energy isomer by 16.5 $\mathrm{kcal} / \mathrm{mol}$. If one assumes that CID takes place from the low-energy $[2 \mathrm{M}-\mathrm{HCl}-\mathrm{Cl}]^{+}$ion $(\mathbf{X X I V})$, the Gibbs energy for the loss of $\mathrm{HCl}$ leading to XXVI is 29.6 $\mathrm{kcal} / \mathrm{mol}$. The corresponding Gibbs energy to form cation $\mathrm{XXV}$ is $46.1 \mathrm{kcal} / \mathrm{mol}$. 
$\left[2 \mathrm{M}-\mathrm{HCl}-\mathrm{Cl}^{+}\right.$. A cation with a $\mathrm{m} / \mathrm{z}$ of 579.0 was detected in $35 \%$ relative abundance in the ESMS from the $\mathrm{H}_{2} \mathrm{O}$ solution. This cation is consistent with the $[2 \mathrm{M}-\mathrm{HCl}-\mathrm{Cl}]^{+}$ion. It is unclear, however, if this ion possesses the structure associated with cation XXIII or XXIV. Depending upon the structure of the $\mathrm{m} / \mathrm{z} 579.0$ ion, the pathway for its formation will vary. The ESMS obtained from the $\mathrm{D}_{2} \mathrm{O}$ solution does not help to clarify the picture, as the associated ion $(\mathrm{m} / \mathrm{z} 586.0,30 \%)$ shows seven hydrogen-deuterium exchanges; both possible isomers have seven exchangeable hydrogen atoms (on the four amino groups).

Subjecting the $[2 \mathrm{M}-\mathrm{HCl}-\mathrm{Cl}]^{+}$ion to $\mathrm{CID}$ results in a single fragment ion with a $m / z$ of 543.0 , presumably the $[2 \mathrm{M}-2 \mathrm{HCl}-\mathrm{Cl}]^{+}$ion. Confirmation of this is seen in the CID of the deuterated analog, where a single fragment ion with a $m / z$ of 550.0 is seen. This increase of $7 \mathrm{u}$ corresponds to complete hydrogendeuterium exchange at the amino positions. The calculated Gibbs energy for this CID process is 36.6 $\mathrm{kcal} / \mathrm{mol}$.

In an attempt to resolve this question, the thermodynamics for the various pathways leading to the formation of the two isomers were explored theoretically. Simple loss of $\mathrm{HCl}$ from the $[2 \mathrm{M}-\mathrm{Cl}]^{+}$ion in solution was calculated. The Gibbs energy leading to the formation of the lower energy cation (XXIV) was determined to be $21.4 \mathrm{kcal} / \mathrm{mol}$, while the corresponding value leading to the higher energy cation (XXIII) was found to be $36.7 \mathrm{kcal} / \mathrm{mol}$. Assuming this to be the only operative mechanism leading to the $[2 \mathrm{M}-\mathrm{HCl}-\mathrm{Cl}]^{+}$ion, the nod would have to be given to cation with the structure of XXIV.

A different pathway for the formation of cation XXIII is outlined in eqs 19 and 20.

$$
\begin{aligned}
& \mathrm{M}+\left[\mathrm{M}-2 \mathrm{Cl}+2 \mathrm{H}_{2} \mathrm{O}\right]^{2+} \rightarrow[2 \mathrm{M}-2 \mathrm{Cl}]^{2+}+2 \mathrm{H}_{2} \mathrm{O} \\
& {[2 \mathrm{M}-2 \mathrm{Cl}]^{2+}+\mathrm{B} \rightarrow \mathrm{BH}^{+}+[2 \mathrm{M}-\mathrm{HCl}-\mathrm{Cl}]^{+}}
\end{aligned}
$$

First, the neutral parent $\mathrm{M}$ reacts with the $[\mathrm{M}-2 \mathrm{Cl}+$ $\left.2 \mathrm{H}_{2} \mathrm{O}\right]^{2+}$ ion to form the (unobserved) $[2 \mathrm{M}-2 \mathrm{Cl}]^{2+}$ ion intermediate in solution. This reaction is calculated to be favorable $\left(\Delta \mathrm{G}_{\mathrm{aq}}[19]=-5.6 \mathrm{kcal} / \mathrm{mol}\right)$. Second, a proton is abstracted from the intermediate ion to form the observed cation (XXIII). If $\mathrm{H}_{2} \mathrm{O}$ serves as the base, this deprotonation is endergonic $\left(\Delta \mathrm{G}_{\mathrm{aq}}(20)=48.1\right.$ $\mathrm{kcal} / \mathrm{mol}$ ). The unfavorable nature of this reaction can be mitigated somewhat if a more basic species is employed; e.g., $\Delta \mathrm{G}_{\mathrm{aq}}(20)=6.7 \mathrm{kcal} / \mathrm{mol}$ when $\mathrm{B}=$ $\mathrm{H}_{2} \mathrm{NCH}_{2} \mathrm{CH}_{2} \mathrm{NH}_{2}$. It should be noted that it is not possible to form cation XXIV via deprotonation as there is not a suitable precursor.

Finally, the two possible isomers for the $[2 \mathrm{M}-\mathrm{HCl}-$ $\mathrm{Cl}^{+}$ion could be formed through a clustering reaction from species present in solution. This is a rather straightforward process in the case of cation XXIII (eq 21).

$$
\mathrm{M}+[\mathrm{M}-\mathrm{HCl}-\mathrm{Cl}]^{+} \rightarrow[2 \mathrm{M}-\mathrm{HCl}-\mathrm{Cl}]^{+}
$$

As noted earlier, there is direct evidence for the [M $\mathrm{HCl}-\mathrm{Cl}]^{+}$ion and neutral $\mathrm{M}$ being present in solution. The calculated Gibbs energy for this reaction is exergonic in the gas-phase $\left(\Delta \mathrm{G}_{\mathrm{gas}}=-61.5 \mathrm{kcal} / \mathrm{mol}\right)$ and solution $\left(\Delta \mathrm{G}_{\mathrm{aq}}=-25.4 \mathrm{kcal} / \mathrm{mol}\right)$.

The formation of the lower energy $[2 \mathrm{M}-\mathrm{HCl}-\mathrm{Cl}]^{+}$ ion via a clustering pathway is more problematic. A possible reaction is given in eq 22, where the presence of the mass spectrometrically silent $[\mathrm{M}-\mathrm{HCl}]$ neutral is required.

$$
\begin{aligned}
& {\left[\mathrm{M}-\mathrm{Cl}+\mathrm{H}_{2} \mathrm{O}\right]^{+}+[\mathrm{M}-\mathrm{HCl}] \rightarrow[2 \mathrm{M}-\mathrm{HCl}-\mathrm{Cl}]^{+}} \\
& \quad+\mathrm{H}_{2} \mathrm{O}
\end{aligned}
$$

Assuming its availability, the reaction is calculated to be exergonic in the gas-phase $\left(\Delta \mathrm{G}_{\text {gas }}=-31.4 \mathrm{kcal} / \mathrm{mol}\right)$ and solution $\left(\Delta \mathrm{G}_{\mathrm{aq}}=-28.1 \mathrm{kcal} / \mathrm{mol}\right)$.

The direct loss of $\mathrm{HCl}$ to yield the $[\mathrm{M}-\mathrm{HCl}]$ neutral could occur from two species (eqs 23 and 24).

$$
\begin{aligned}
& \mathrm{M} \rightarrow[\mathrm{M}-\mathrm{HCl}]+\mathrm{HCl} \\
& {\left[\mathrm{M}-\mathrm{Cl}+\mathrm{H}_{2} \mathrm{O}\right]^{+} \rightarrow[\mathrm{M}-\mathrm{HCl}]+\mathrm{H}_{3} \mathrm{O}^{+}}
\end{aligned}
$$

Both reactions are endergonic in the gas-phase $\left(\Delta G_{\text {gas }}\right.$ $(23)=35.4$ and $\left.\Delta G_{\text {gas }}(24)=91.4 \mathrm{kcal} / \mathrm{mol}\right)$. The unfavorable nature of the reaction in eq 24 is moderated somewhat if it occurs in solution $\left(\Delta \mathrm{G}_{\mathrm{aq}}=53.9 \mathrm{kcal} /\right.$ $\mathrm{mol})$, but it actually worsens for the reaction in eq 23 $\left(\Delta \mathrm{G}_{\mathrm{aq}}=50.3 \mathrm{kcal} / \mathrm{mol}\right)$.

$[2 \mathrm{M}-2 \mathrm{HCl}-\mathrm{Cl}]^{+}$. Evidence for the $[2 \mathrm{M}-2 \mathrm{HCl}-$ $\mathrm{Cl}]^{+}$ion was also found in the ESMS from the $\mathrm{H}_{2} \mathrm{O}$ solution, where a cation with a $\mathrm{m} / \mathrm{z}$ of 543.0 was detected in 35\% relative abundance. The corresponding cation derived from the $\mathrm{D}_{2} \mathrm{O}$ solution was seen to have a $\mathrm{m} / \mathrm{z}$ of 549.0 in $25 \%$ relative abundance. This increase of $6 \mathrm{u}$ represents six hydrogen-deuterium exchanges. As was the case for the $[2 \mathrm{M}-\mathrm{HCl}-\mathrm{Cl}]^{+}$ion, two possible structures exist for the $[2 \mathrm{M}-2 \mathrm{HCl}-\mathrm{Cl}]^{+}$ion (XXV and XXVI), and this hydrogen-deuterium exchange data does not elucidate which structure is correct as both isomers possess six exchangeable hydrogen atoms.

Collision-induced dissociation of the $[2 \mathrm{M}-2 \mathrm{HCl}-$ $\mathrm{Cl}^{+}$ion leads to three fragment ions with $\mathrm{m} / \mathrm{z}$ of 526.0 $(100 \%), 507.0(35 \%)$, and $490.0(10 \%)$. The $m / z 526.0$ ion is formed via the loss of $\mathrm{NH}_{3}$ to produce a $[2 \mathrm{M}-2 \mathrm{HCl}-$ $\left.\mathrm{Cl}-\mathrm{NH}_{3}\right]^{+}$ion (XXVII). The theoretical Gibbs energy for this loss of $\mathrm{NH}_{3}$ is $46.9 \mathrm{kcal} / \mathrm{mol}$. The $\mathrm{m} / \mathrm{z} 507.0$ ion is produced through the loss of $\mathrm{HCl}$ to yield the [2M $3 \mathrm{HCl}-\mathrm{Cl}^{+}$ion (XXVIII), which is only slightly more endergonic, where the Gibbs energy is calculated to be $50.1 \mathrm{kcal} / \mathrm{mol}$. The structure results from the bridging of the two Pt atoms by two deprotonated amino groups. Finally, the $m / z 490.0$ fragment ion is 
generated from the loss of both $\mathrm{NH}_{3}$ and $\mathrm{HCl}$ to yield the $\left[2 \mathrm{M}-3 \mathrm{HCl}-\mathrm{Cl}-\mathrm{NH}_{3}\right]^{+}$ion (XXIX). As would be expected, the loss of both $\mathrm{HCl}$ and $\mathrm{NH}_{3}$ requires substantially more energy $\left(\Delta \mathrm{G}_{\text {gas }}=94.0 \mathrm{kcal} / \mathrm{mol}\right)$. When the deuterated $[2 \mathrm{M}-2 \mathrm{HCl}-\mathrm{Cl}]^{+}$analog is subjected to CID, three fragment ions are also produced that are consistent with their hydrogen counterparts evincing complete hydrogen-deuterium exchange at the amino groups: 530.0 (100\%), 512.0 $(35 \%)$, and $497.0(10 \%)$.
XXVII

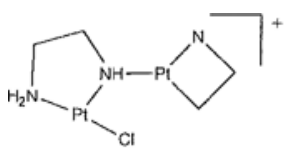

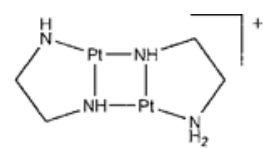

XXVIII

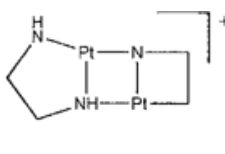

$\mathbf{X X I X}$
The possibility of the direct loss of $\mathrm{HCl}$ from the lower energy $\left[2 \mathrm{M}-\mathrm{HCl}-\mathrm{Cl}^{+}\right.$ion (XXIV) in solution was assessed by theory. Here, the Gibbs energy leading to XXVI was calculated to be $38.0 \mathrm{kcal} / \mathrm{mol}$, while the same value leading to XXV was determined to be $55.3 \mathrm{kcal} / \mathrm{mol}$. These respective values only increase, of course, if the higher energy $[2 \mathrm{M}-\mathrm{HCl}-\mathrm{Cl}]^{+}$ion $(\mathbf{X X I I I})$ is considered.

It is possible to form cation $\mathbf{X X V}$ via deprotonation of a dicationic precursor (eq 25).

$$
[2 \mathrm{M}-\mathrm{HCl}-2 \mathrm{Cl}]^{2+}+\mathrm{B} \rightarrow \mathrm{BH}^{+}+[2 \mathrm{M}-2 \mathrm{HCl}-\mathrm{Cl}]^{+}
$$

The Gibbs energy for this proton transfer reaction is calculated to be $51.0 \mathrm{kcal} / \mathrm{mol}$ when the base is $\mathrm{H}_{2} \mathrm{O}$. Once again, the reaction can be made more favorable if a stronger base is used; e.g., $\Delta \mathrm{G}_{\mathrm{aq}}=9.6 \mathrm{kcal} / \mathrm{mol}$ when $\mathrm{B}=$ $\mathrm{H}_{2} \mathrm{NCH}_{2} \mathrm{CH}_{2} \mathrm{NH}_{2}$. No precursor exists, however, that can be deprotonated to lead to the lower energy cation XXVI.

It is also possible to form the $[2 \mathrm{M}-2 \mathrm{HCl}-\mathrm{Cl}]^{+}$ion via a clustering reaction. From the same reactants, the $[\mathrm{M}$ $-\mathrm{HCl}-\mathrm{Cl}]^{+}$ion and $[\mathrm{M}-\mathrm{HCl}]$ neutral, the two possible $[2 \mathrm{M}-2 \mathrm{HCl}-\mathrm{Cl}]^{+}$ions can be formed (eq 26).

$$
\begin{gathered}
{[\mathrm{M}-\mathrm{HCl}-\mathrm{Cl}]^{+}+[\mathrm{M}-\mathrm{HCl}] \rightarrow[2 \mathrm{M}-2 \mathrm{HCl}} \\
-\mathrm{Cl}]^{+}(\mathbf{X X V})+[2 \mathrm{M}-2 \mathrm{HCl}-\mathrm{Cl}]^{+}(\mathbf{X X V I})
\end{gathered}
$$

The formation of both cations is predicted to exergonic in the gas-phase $\left(\Delta \mathrm{G}_{\text {gas }}=-59.8 \mathrm{kcal} / \mathrm{mol}\right.$ for $\mathbf{X X V}$ and $\Delta \mathrm{G}_{\text {gas }}=-76.3 \mathrm{kcal} / \mathrm{mol}$ for XXVI $)$ and solution $\left(\Delta \mathrm{G}_{\mathrm{aq}}=\right.$ $-40.7 \mathrm{kcal} / \mathrm{mol}$ for $\mathrm{XXV}$ and $\Delta \mathrm{G}_{\mathrm{aq}}=-58.0 \mathrm{kcal} / \mathrm{mol}$ for XXVI).

$\left[2 \mathrm{M}-\mathrm{HCl}-\mathrm{Cl}+\mathrm{H}_{2} \mathrm{O}\right]^{+}$. The detection of a cation with a $m / z$ of 597.0 in $35 \%$ relative abundance in the $\mathrm{H}_{2} \mathrm{O}$ ESMS is consistent with a $\left[2 \mathrm{M}-\mathrm{HCl}-\mathrm{Cl}+\mathrm{H}_{2} \mathrm{O}\right]^{+}$ion. The ESMS derived from the $\mathrm{D}_{2} \mathrm{O}$ solution evinces an ion with a $\mathrm{m} / \mathrm{z}$ of 606.0 in $15 \%$ relative abundance, which would correspond to nine hydrogen-deuterium exchanges.

When these ions undergo CID, each leads to three fragment ions. One of these ions is produced by the loss of $\mathrm{H}_{2} \mathrm{O}\left(\mathrm{D}_{2} \mathrm{O}\right)$ to yield the $[2 \mathrm{M}-\mathrm{HCl}-\mathrm{Cl}]^{+}$ion with a $\mathrm{m} / \mathrm{z}$ of $579.0(586.0)$ in $100 \%(100 \%)$ relative abundance. The second of these ions is formed from the loss of $\mathrm{HCl}(\mathrm{DCl})$ leading to the $[2 \mathrm{M}-2 \mathrm{HCl}-\mathrm{Cl}+$ $\mathrm{H}_{2} \mathrm{O}^{+}$ion with a $\mathrm{m} / \mathrm{z}$ of $561.0(569.0)$ in a $30 \%(35 \%)$ relative abundance. The final fragment ion is obtained through the loss of both $\mathrm{H}_{2} \mathrm{O}\left(\mathrm{D}_{2} \mathrm{O}\right)$ and $\mathrm{HCl}(\mathrm{DCl})$ to produce the $[2 \mathrm{M}-2 \mathrm{HCl}-\mathrm{Cl}]^{+}$ion with a $\mathrm{m} / \mathrm{z}$ of 543.0 (549.0) in a relative abundance of 30\% (45\%).

Theoretical calculations reveal the low-energy isomer for the $\left[2 \mathrm{M}-\mathrm{HCl}-\mathrm{Cl}+\mathrm{H}_{2} \mathrm{O}\right]^{+}$ion to be composed of two $[\mathrm{Pt}(\mathrm{en}) \mathrm{Cl}]^{+}$ions bridged by $\mathrm{OH}$ ligand $(\mathbf{X X X})$. Based upon this structure, the Gibbs energy for the loss $\mathrm{H}_{2} \mathrm{O}$ is calculated to be only 28.8 $\mathrm{kcal} / \mathrm{mol}$, the structure of the resulting ion being the lower energy [2M $-\mathrm{HCl}-\mathrm{Cl}]^{+}$ion (XXIV). Similarly, the theoretical Gibbs energy for the formation of the $[2 \mathrm{M}-2 \mathrm{HCl}-\mathrm{Cl}]^{+}$ion $($XXIII) is $49.5 \mathrm{kcal} / \mathrm{mol}$.

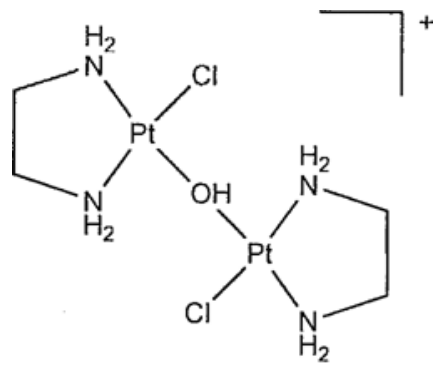

$\mathbf{X X X}$

The $m / z 561.0$ (569.0) ion was not previously observed in the ES nor the CID mass spectra. Theoretical calculations show this ion to be formed by bridging chloride and oxo groups (XXXI). The Gibbs energy for its formation via CID is predicted to be $49.4 \mathrm{kcal} / \mathrm{mol}$.

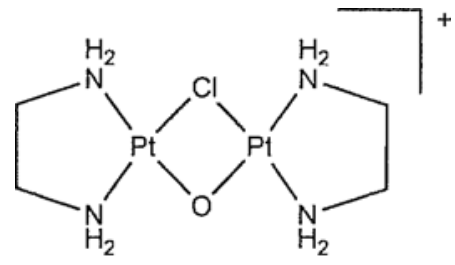

\section{$\mathbf{X X X I}$}

The formation of the $\left[2 \mathrm{M}-\mathrm{HCl}-\mathrm{Cl}+\mathrm{H}_{2} \mathrm{O}\right]^{+}$ion could occur by the clustering of the $[\mathrm{M}-\mathrm{HCl}]$ neutral with the $\left[\mathrm{M}-\mathrm{Cl}+\mathrm{H}_{2} \mathrm{O}\right]^{+}$ion to yield the cation intermediate XXXII (eq 27), followed by proton transfer from the bridging $\mathrm{H}_{2} \mathrm{O}$ group to the deprotonated amino group ( $\mathbf{X X X}$, eq 28).

$$
\begin{aligned}
& {[\mathrm{M}-\mathrm{HCl}]+\left[\mathrm{M}-\mathrm{Cl}+\mathrm{H}_{2} \mathrm{O}\right]^{+} \rightarrow[2 \mathrm{M}-\mathrm{HCl}-\mathrm{Cl}} \\
& \left.\quad+\mathrm{H}_{2} \mathrm{O}\right]^{+}
\end{aligned}
$$




$$
\left[2 \mathrm{M}-\mathrm{HCl}-\mathrm{Cl}+\mathrm{H}_{2} \mathrm{O}\right]^{+} \rightarrow\left[2 \mathrm{M}-\mathrm{HCl}-\mathrm{Cl}+\mathrm{H}_{2} \mathrm{O}\right]^{+}
$$

The total Gibbs energy for the formation of the final ion is calculated to be $-51.3 \mathrm{kcal} / \mathrm{mol}$ in the gas-phase and $-32.6 \mathrm{kcal} / \mathrm{mol}$ in solution.

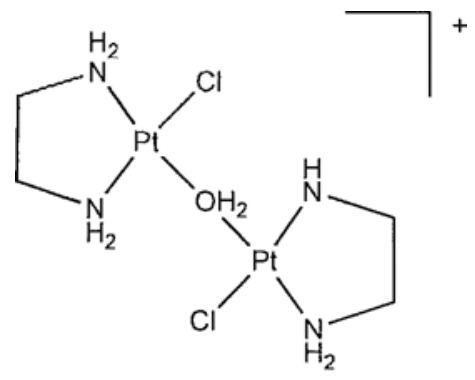

XXXII

\section{Trimetallic Cations}

$\left[3 \mathrm{M}-\mathrm{HCl}-\mathrm{Cl}+\mathrm{H}_{2} \mathrm{O}\right]^{+}$and $[3 \mathrm{M}-\mathrm{Cl}]^{+}$. The final cations observed are consistent with the formation of trimer-like moieties. The cation observed with a $\mathrm{m} / \mathrm{z}$ of 944.0 in $5 \%$ relative abundance is postulated to be the $[3 \mathrm{M}-\mathrm{Cl}]^{+}$ion. This is further confirmed from the ESMS of the deuterated solution, where twelve deuterium incorporations are seen. The theoretical structure for this cation consists of four hydrogen bonds between the $[2 \mathrm{M}-\mathrm{Cl}]^{+}$ion and the $\mathrm{M}$ neutral (XXXIII). This cation can be formed in the gas-phase by clustering the parent neutral with the $[2 \mathrm{M}-\mathrm{Cl}]^{+}$ ion (eq 29),

$$
[2 \mathrm{M}-\mathrm{Cl}]^{+}+\mathrm{M} \rightarrow[3 \mathrm{M}-\mathrm{Cl}]+
$$

where the Gibbs energy is predicted to be $-16.1 \mathrm{kcal} /$ mol. The weak nature of this interaction is evidenced in the CID where $\mathrm{M}$ is easily lost to form the $[2 \mathrm{M}-\mathrm{Cl}]^{+}$ fragment ion in $100 \%$ relative abundance.

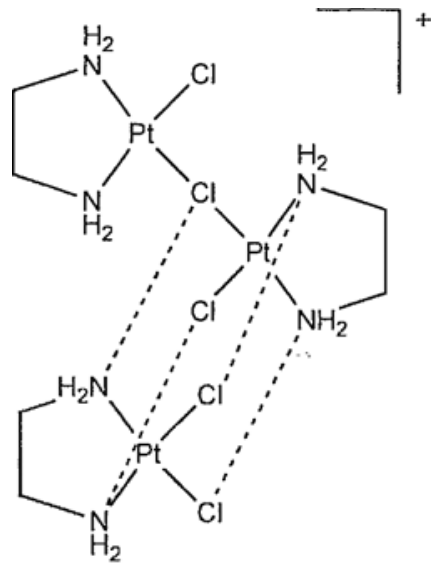

XXXIII
The peaks detected at $m / z 922.0$ is consistent with a $\left[3 \mathrm{M}-\mathrm{HCl}-\mathrm{Cl}+\mathrm{H}_{2} \mathrm{O}\right]^{+}$ion $($XXXIV), which can be formed from the $\left[2 \mathrm{M}-\mathrm{HCl}-\mathrm{Cl}+\mathrm{H}_{2} \mathrm{O}\right]^{+}$ion clustering with the parent neutral molecule (eq 30).

$$
\begin{aligned}
& {\left[2 \mathrm{M}-\mathrm{HCl}-\mathrm{Cl}+\mathrm{H}_{2} \mathrm{O}\right]^{+}+\mathrm{M} \rightarrow[3 \mathrm{M}-\mathrm{HCl}-\mathrm{Cl}} \\
& \left.\quad+\mathrm{H}_{2} \mathrm{O}\right]^{+}
\end{aligned}
$$

Once again, the non-covalent nature of this interaction is attested to by the small clustering energy in the gas-phase $\left(\Delta \mathrm{G}_{\text {gas }}=-14.2 \mathrm{kcal} / \mathrm{mol}\right)$. This structure should evince up to 13 hydrogen-deuterium exchanges and the incorporation of $\mathrm{a}_{2} \mathrm{O}$ molecule; this is what is seen in the ESMS obtained from the $\mathrm{D}_{2} \mathrm{O}$ solution $(\mathrm{m} / \mathrm{z}$ 935.0, 10\%).

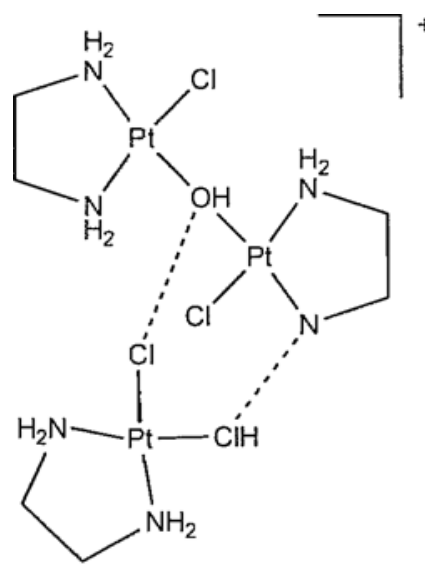

XXXIV

\section{Comparison with $\mathrm{Pd}(\mathrm{en}) \mathrm{Cl}_{2}$}

Merrill et al. have previously examined the hydrolysis products of $\mathrm{Pd}(\mathrm{en}) \mathrm{Cl}_{2}$ via electrospray mass spectrometry (ESMS) [6]. It is, therefore, possible to assess the impact of the metal ( $\mathrm{Pd}$ versus $\mathrm{Pt})$ on the hydrolysis process. As was seen in the ESMS for the platinum compound, the base peak observed in the $\mathrm{Pd}(\mathrm{en}) \mathrm{Cl}_{2}$ ESMS was the $[2 \mathrm{M}-\mathrm{X}]^{+}$ion. Similarly, the $[\mathrm{M}-\mathrm{X}+$ $\mathrm{H}_{2} \mathrm{O}^{+}$ion was observed in the next greatest abundance $(80 \%)$ in the palladium spectrum. Of the seven major ions observed in the $\mathrm{Pt}(\mathrm{en}) \mathrm{Cl}_{2}$ ESMS, five are also seen in the $\mathrm{Pd}(\mathrm{en}) \mathrm{Cl}_{2}$ spectrum with roughly the same relative abundances. The two exceptions are the $[\mathrm{M}-2 \mathrm{Cl}+$ en $]^{2+}$ and $[\mathrm{M}-\mathrm{HCl}-\mathrm{Cl}+\text { en }]^{+}$ions; this differences suggests that loss of the en ligand is more difficult when it is attached to a $\mathrm{Pd}$ atom. Some evidence for the limited hydrolysis of the en group in the $\mathrm{Pd}(\mathrm{en}) \mathrm{Cl}_{2}$ compound is seen in the presence of the $[\mathrm{M}-\mathrm{X}+\mathrm{en}]^{+}$ ion in a $5 \%$ relative abundance.

The principle differences between the two spectra involve the minor monometallic ions observed in the $\mathrm{Pt}(\mathrm{en}) \mathrm{Cl}_{2}$ ESMS, none of which were detected in the $\mathrm{Pd}(\mathrm{en}) \mathrm{Cl}_{2}$ spectrum. Two of these species, [M $-\mathrm{HCl}-$ 
$\left.\mathrm{Cl}-\mathrm{NH}_{3}\right]^{+}$and $\left[\mathrm{M}-2 \mathrm{Cl}+\mathrm{CH}_{2} \mathrm{~N}\right]^{+}$, are putatively formed via the fragmentation of the en ligand. This difference suggests that the $\mathrm{Pt}$ atom is more catalytic than the $\mathrm{Pd}$ atom. The other two ions $\left([\mathrm{M}-\mathrm{HCl}-\mathrm{Cl}]^{+}\right.$ and $\left[\mathrm{M}-\mathrm{HCl}-\mathrm{Cl}+\mathrm{H}_{2} \mathrm{O}\right]^{+}$) missing from the palladium spectrum demonstrate that the $[\mathrm{M}-\mathrm{HCl}-$ $\mathrm{Cl}]^{+}$ion is more reactive than its palladium analog. The absence of this cation may simply result from its incorporation into bimetallic species (e.g., the [2M - 3HX $\mathrm{X}]^{+}$ion).

Two final differences between the palladium and platinum ESMS are the absence of two ions in the platinum spectrum: the $[2 \mathrm{M}-3 \mathrm{HX}-\mathrm{X}]^{+}$ion (detected with a $25 \%$ relative abundance) and the absence $[\mathrm{M}-$ $\mathrm{X}^{+}$ion (detected in $5 \%$ relative abundance).

\section{Conclusions}

When a dilute aqueous solution of $\mathrm{Pt}(\mathrm{en}) \mathrm{Cl}_{2}$ is electrosprayed into a quadrupole ion-trap mass spectrometer, a bimetallic cation, $[2 \mathrm{M}-\mathrm{Cl}]^{+}$, was observed in greatest abundance $(100 \%)$. This cation is putatively formed by the reaction of the parent compound with the partially hydrolyzed $\left[\mathrm{M}-\mathrm{Cl}+\mathrm{H}_{2} \mathrm{O}\right]^{+}$ion, which itself was observed in next greatest abundance $(70 \%)$. While no direct evidence for the completely hydrolyzed parent was found, $\left[\mathrm{M}-2 \mathrm{Cl}+2 \mathrm{H}_{2} \mathrm{O}\right]^{2+}$, its presence in solution was inferred from the presence of observed cations formed through reactions involving this diaqua species.

In addition to the $[2 \mathrm{M}-\mathrm{Cl}]^{+}$ion, a number of other bimetallic cations formed via the sequential loss of $\mathrm{HCl}$ were also detected. Similarly, two trimetallic cations were seen, including the $[3 \mathrm{M}-\mathrm{Cl}]^{+}$ion, supposedly formed via ion-molecule reactions.

These results are essentially consistent with those previously obtained from dilute aqueous solutions of $\mathrm{Pd}(\mathrm{en}) \mathrm{Cl}_{2}$ [6]. Where the platinum and palladium solutions appear to differ most is with respect to monometallic species. Specifically, the solution derived from $\mathrm{Pt}(\mathrm{en}) \mathrm{Cl}_{2}$ showed signs of hydrolysis of the ethylenediamine ligand as demonstrated by the presence of the $[2 \mathrm{M}-2 \mathrm{Cl}+\mathrm{en}]^{2+}$ and $[\mathrm{M}-\mathrm{HCl}-\mathrm{Cl}+\mathrm{en}]^{+}$ions. Additionally, evidence for the fragmentation of the ethylenediamine ligand was seen in the $\mathrm{Pt}(\mathrm{en}) \mathrm{Cl}_{2}$ solution vis-à-vis the $\left[\mathrm{M}-\mathrm{HCl}-\mathrm{Cl}-\mathrm{NH}_{3}\right]^{+}$and $[\mathrm{M}-$ $\left.\mathrm{HCl}-\mathrm{Cl}+\mathrm{CH}_{2}=\mathrm{NH}\right]^{+}$ions. Neither of these results was seen in the spectra derived from aqueous $\mathrm{Pd}(\mathrm{en}) \mathrm{Cl}_{2}$ solutions. These differences suggest that ligand stability may be an issue for platinum-containing drugs, especially conditions of high concentration.

\section{References}

1. Rosenberg, B.; Van Camp, L.; Trosko, J. R.; Mansour, V. A. Platinum Compounds: A New Class of Potent Antitumor Agents. Nature 1969, 222,385

2. Sherman, S. E.; Lippard, S. J. Structural Aspects of Platinum Anticancer Drug Interactions with DNA. Chem. Rev. 1987, 87, 1153-1181.

3. Platinum-Based Drugs in Cancer Therapy; Kendall, L. R.; Farrell, N. P., Eds. Humana Press: Totowa, NJ, 2000.
4. (a) Fuertes, M. A.; Alonso, C.; Perez, J. M. Biochemical Modulation of Cisplatin Mechanisms of Action: Enhancement of Antitumor Activity and Circumvention of Drug Resistance. Chem. Rev. 2003, 103, 645-662. (b) Kasparkova, J.; Zehnulova, J.; Farrell, N.; Brabec, V. DNA Interstrand Cross-links of the Novel Antitumor Trinuclear Platinum Complex BBR3464. Conformation, Recognition by High Mobility Group Domain Proteins, and Nucleotide Excision Repair. J. Biol. Chem. 2002 277, 48076-48086. (c) Wyatt, K. S.; Harrison, K. N.; Jensen, C. M. Release of Platinum from Cysteine Residues Induced by N,S-Donor Chelation. Inorg. Chem. 1992, 31, 3867-3868. (d) Martin, R. B. Platinum Complexes: Hydrolysis and Binding to N(7) and N(1) of Purines; Wiley VCH: New York, 1999.

5. Djuran, M. I.; Lempers, E. L. M.; Reedijk, J. Reactivity of Chloroand Aqua(Diethylenetriamine) Platinum(II) Ions with Glutathione, SMethylglutathione, and Guanosine 5'-Monophosphate in Relation to the Antitumor Activity and Toxicity of Platinum Complexes. Inorg. Chem. 1991, 30, 2648-2652.

6. (a) Bach, S. B. H.; Sepeda, T. G.; Merrill, G. N.; Walmsley, J. A. J. Am. Soc. Mass Spectrom. 2005, 16, 1461-1469. (b) Bach, S. B. H.; Green, C. E.; Nagore, L. I.; Sepeda, T. G.; Merrill, G. N. Complexes of Dichloro(Ethylenediamine)Palladium(II) Observed from Aqueous Solutions by Electrospray Mass Spectrometry. J. Am. Soc. Mass Spectrom. 2007, 18 , 769-777.

7. Rochon, F. D.; Buculei, V. Multinuclear Magnetic Resonance Spectroscopy and Crystal Structures of Iodo-bridged Dinuclear Pt(II) Complexes with Amines. Inorg. Chim. Acta 2005, 358, 3919-3926.

8. (a) Henderson, W.; Sabat, M. Platinum(II)- and Palladium(II)-Amide Complexes $\left[\mathrm{M}\left\{\mathrm{NC}(\mathrm{O}) \mathrm{CH}_{2} \mathrm{CH}_{2} \mathrm{CH}_{2}\right\}_{2} \mathrm{~L}_{2}\right]$ Derived from 2-Azetidinone (b-Propiolactam); a Synthetic, Electrospray Mass Spectrometric and X-Ray Crystallographic Study. Polyhedron, 1997, 16, 1663-1677. (b) Vrkic, A. K.; O'Hair, R. A. J. Gas Phase Ion Chemistry of ParaSubstituted Benzene Diazonium Ions, Their Salt Clusters and Their Related Phenyl Cations. Int. J. Mass Spectrom. 2002, 218, 131-160.

9. Shukla, A. K.; Futrell, J. H. Tandem Mass Spectrometry: Dissociation of Ions by Collisional Activation. J. Mass Spectrom. 2000, 35, 1069-1090.

10. (a) Becke, A. D. Density-Functional Exchange-Energy Approximation with Correct Asymptotic Behavior. Phys. Rev. 1988, A38, 3098-3100. (b) Lee, C.; Yang, W.; Parr, R. G. Development of the Colle-Salvetti Correlation-Energy Formula into a Functional of the Electron Density. Phys. Rev. 1988, B37, 785-789. (c) Becke, A. D. A New Mixing of Hartree-Fock and Local-Density-Functional Theories J. Chem. Phys. 1993, 98, 1372-1377.

11. (a) Stevens, W. J.; Basch, H.; Krauss, M. J. Compact Effective Potentials and Efficient Shared-Exponent Basis Sets for the First- and Second-Row Atoms. J. Chem. Phys. 1984, 81, 6026-6033. (b) Stevens, W. J.; Krauss, M. J.; Basch, H.; Jasien, P. G. Relativistic Compact Effective Potentials and Efficient, Shared-Exponent Basis Sets for the Third-, Fourth-, and Fifth-Row Atoms. Canad. J. Chem. 1992, 70, 612-630. (c) Cundari, T. R.; Stevens, W. J. Effective Core Potential Methods for the Lanthanides. J. Chem. Phys. 1993, 98, 5555-5565.

12. Hariharan, P. C.; Pople, J. A. The Influence of Polarization Functions on Molecular Orbital Hydrogenation Energies. Theor. Chim. Acto 1973, 28, 213-222.

13. Pierotti, R. A. A Scaled Particle Theory of Aqueous and Nonaqueous Solutions. Chem. Rev. 1976, 76, 717-726.

14. Langlet, J.; Claverie, P.; Caillet, J.; Pullman, A. Improvements of the Continuum Model. 1. Applications to the Calculation of the Vaporization Thermodynamic Quantities of Nonassociated Liquids. J. Phys. Chem. 1988, 92, 1617-1631.

15. Amovilli, C.; Mennucci, B. Self-Consistent Field Calculation of Pauli Repulsion and Dispersion Contributions to the Solvation Free Energy in the Polarizable Continuum Model. J. Phys. Chem. B 1997, 101, 1051-1057.

16. Mennucci, B.; Tomasi, J. Continuum Solvation Models: A New Approach to the Problem of Solute's Charge Distribution and Cavity Boundaries. J. Chem. Phys. 1997, 106, 5151-5158.

17. Schmidt, M. W.; Baldridge, K. K.; Boatz, J. A.; Elbert, S. T.; Gordon, M. S.; Jensen, J. H.; Koseki, S.; Matsunaga, N.; Nguyen, K. A.; Su, S. Windus, T. L.; Montgomery, J.; Dupuis, M. General Atomic and Molecular Electronic Structure System. J. Comput. Chem. 1993, 14, 1347-1363.

18. Coley, R. F.; Martin, D. S. Kinetics and Equilibria for the Acid Hydrolysis of Dichloro(Ethylenediamine)Platinum(II). Inorg. Chim. Acta. 1973, 7, 573577.

19. Costa, L. A. S.; Rocha, W. R.; De Almeida, W. B.; Dos Santos, H. F. The Hydrolysis Process of the cis-Dichloro(Ethylenediamine)Platinum(II): A Theoretical Study. J. Chem. Phys. 2003, 118, 10584-10592.

20. Costa, L. A. S.; Rocha, W. R.; De Almeida, W. B.; Dos Santos, H. F. The Solvent Effect on the Aquation Processes of the cis-Dichloro(Ethylenediamine)Platinum(II) Using Continuum Solvation Models. Chem. Phys. Lett. 2004, 387, 182-187.

21. (a) Møller, C.; Plesset, M. S. Note on the Approximation Treatment for Many-Electron Systems. Phys. Rev. 1934, 46, 618-622. (b) Binkley, J. S. Pople, J. A. Møller-Plesset Theory for Atomic State Energies. Int. J. Quantum Chem. 1975, 9, 229-236.

22. Henderson, W.; Nicholson, B. K.; McCaffrey, L. J. Applications of Electrospray Mass Spectrometry in Organometallic Chemistry. Polyhedron 1998, 17, 4291-4313.

23. Somorjai, G. A.; Rupprechter, G. The Flexible Surface: Molecular Studies Explain the Extraordinary Diversity of Surface Chemical Properties. J. Chem. Edu. 1998, 75, 162-176. 